\title{
ॠUSGS
}

science for a changing world

\section{Digital Tabulation of Stratigraphic Data from Oil And Gas Wells in Cuyama Valley and Surrounding Areas, Central California}

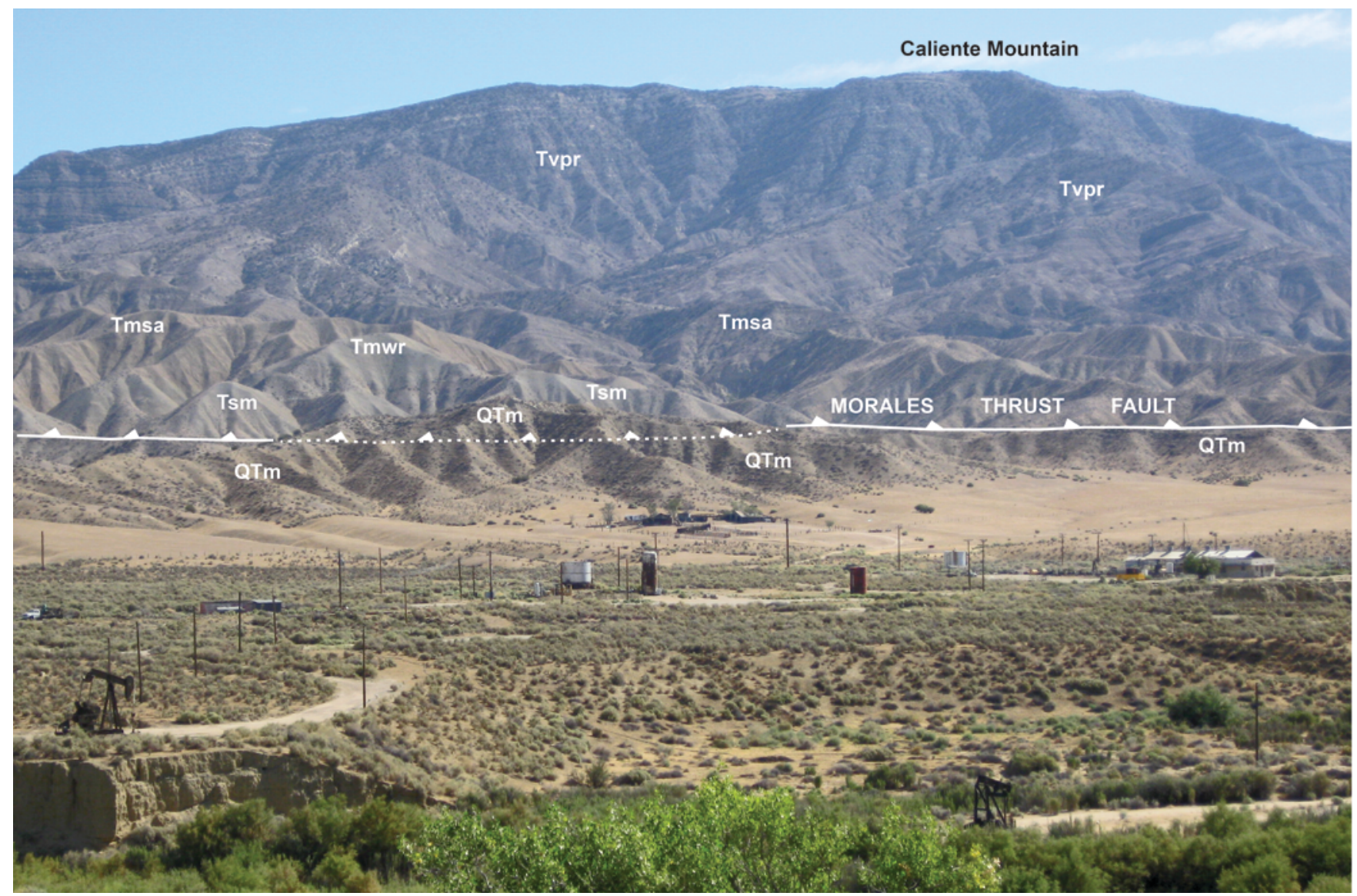

Open-File Report 2013-1084

U.S. Department of the Interior

U.S. Geological Survey 
Cover: Looking northeast from Cuyama Valley to Caliente Mountain. Producing oil wells in part of the Russell Ranch field in foreground. QTm, Morales Formation; Tsm, Santa Margarita Formation; Tmwr, Whiterock Bluff Shale Member of the Monterey Formation; Tmsa, Saltos Shale Member of the Monterey Formation; Tvpr, Painted Rock Sandstone Member of the Vaqueros Formation. Dotted fault indicates concealed by topography. Photograph taken by Donald S. Sweetkind, U.S. Geological Survey, August 5, 2009. 


\section{Digital Tabulation of Stratigraphic Data from Oil And Gas Wells in Cuyama Valley and Surrounding Areas, Central California}

By Donald S. Sweetkind, Shiera C. Bova, Victoria E. Langenheim, Lauren E. Shumaker, and Daniel S. Scheirer

Open-File Report 2013-1084

U.S. Department of the Interior

U.S. Geological Survey 


\section{U.S. Department of the Interior \\ SALLY JEWELL, Secretary}

\section{U.S. Geological Survey \\ Suzette M. Kimball, Acting Director}

U.S. Geological Survey, Reston, Virginia: 2013

For more information on the USGS—-the Federal source for science about the Earth, its natural and living resources, natural hazards, and the environment-visit http://www.usgs.gov or call 1-888-ASK-USGS

For an overview of USGS information products, including maps, imagery, and publications, visit $h$ ttp://www.usgs.gov/pubprod

To order this and other USGS information products, visit http://store.usgs.gov

Suggested citation:

Sweetkind, D.S., Bova, S.C., Langenheim, V.E., Shumaker, L.E., and Scheirer, D.S., 2013, Digital tabulation of stratigraphic data from oil and gas wells in Cuyama Valley and surrounding areas, central California: U.S. Geological Survey Open-File Report 2013-1084, 44 p., http://pubs.usgs.gov/of/2013/1084/.

Any use of trade, firm, or product names is for descriptive purposes only and does not imply endorsement by the U.S. Government.

Although this information product, for the most part, is in the public domain, it also may contain copyrighted materials as noted in the text. Permission to reproduce copyrighted items must be secured from the copyright owner. 


\section{Contents}

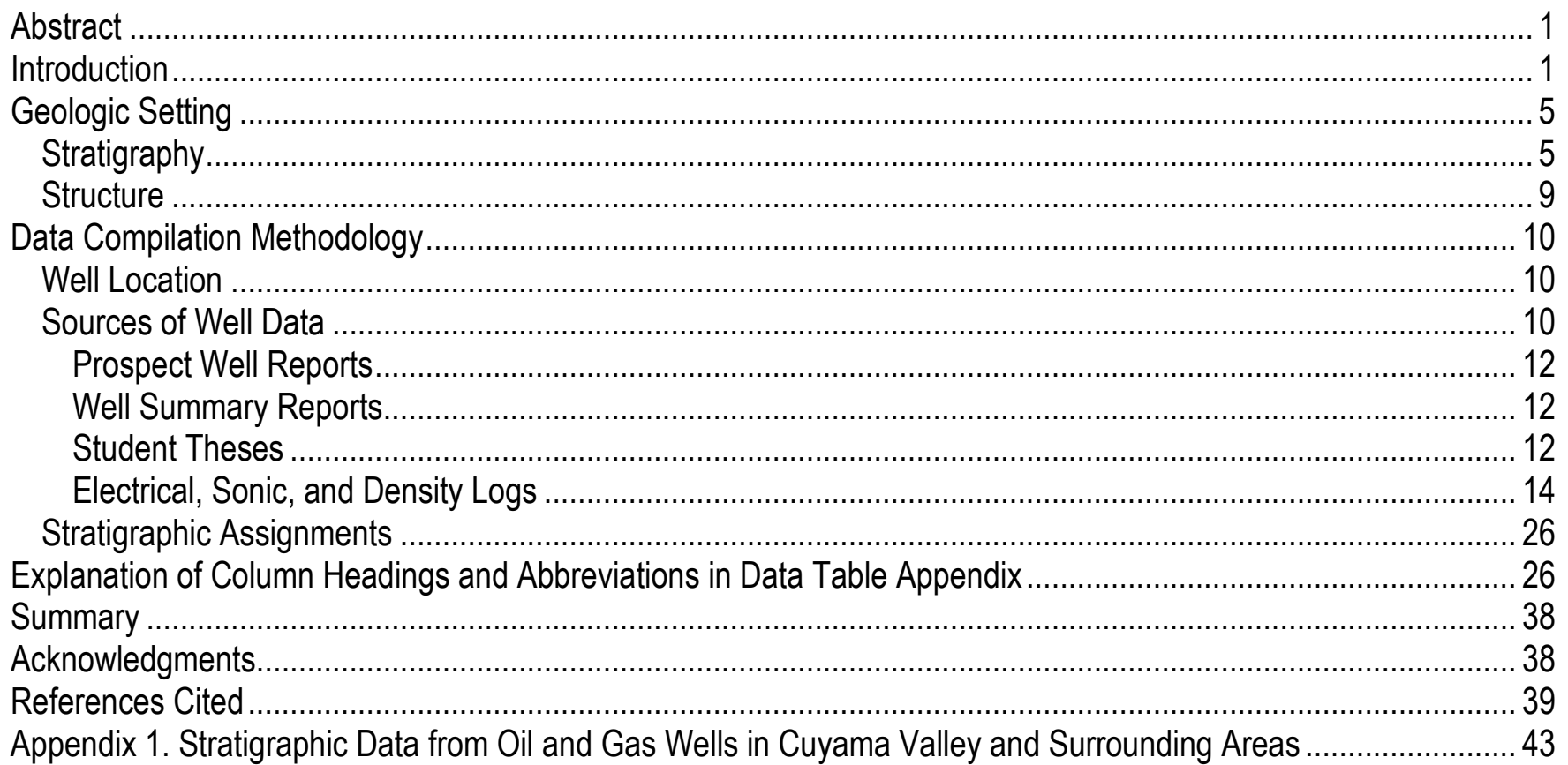




\section{Figures}

1. Generalized geologic map of the Cuyama Basin and surrounding region ................................................... 3

2. Geologic map of Cuyama Valley and surrounding ranges .................................................................. 4

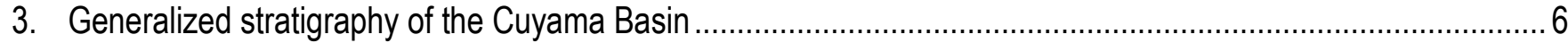

4. Diagrammatic northwest-southeast stratigraphic section across the Cuyama Basin...................................... 8

5. Map showing location of oil and gas wells in Cuyama Valley and surrounding areas, symbolized by source of subsurface stratigraphic data............................................................................................ 11

6. Map showing location of student thesis areas and subsurface cross sections in Cuyama Valley ...................... 13

7. Map showing location of wells with example electric logs and wells with sonic and density logs in Cuyama

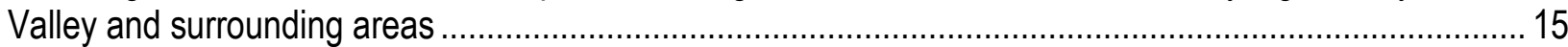

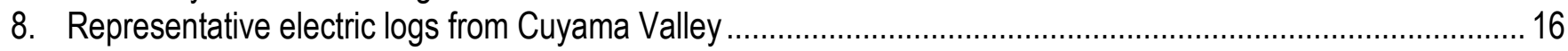

9. Sonic and density logs from wells in Cuyama Valley and surrounding areas................................................ 20

10. Map showing the location of wells in Cuyama Valley where the stratigraphic section is not duplicated by thrusting, and the location of wells in surrounding range blocks where the section is repeated by one

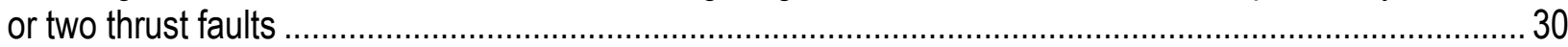

11. Map showing the location of wells in Cuyama Valley that penetrate granite or granitic gneiss at depth ............37 


\section{Conversion Factors}

\begin{tabular}{lcl}
\hline \multicolumn{1}{c}{ Multiply } & By & \multicolumn{1}{c}{ To obtain } \\
\hline centimeter $(\mathrm{cm})$ & 0.3937 & inch (in.) \\
meter $(\mathrm{m})$ & 3.281 & foot $(\mathrm{ft})$ \\
kilometer $(\mathrm{km})$ & 0.6214 & mile $(\mathrm{mi})$ \\
meter $(\mathrm{m})$ & 1.094 & yard $(\mathrm{yd})$ \\
\hline & Volume & \\
\hline cubic meter $\left(\mathrm{m}^{3}\right)$ & 6.290 & barrel $($ petroleum, $1 \mathrm{barrel}=42$ \\
& & gallons $)$ \\
\hline & Density & \\
\hline gram per cubic centimeter $\left(\mathrm{g} / \mathrm{cm}^{3}\right)$ & 62.428 & pound per cubic foot $\left(\mathrm{lb} / \mathrm{ft}^{3}\right)$ \\
\hline & Interval velocity & \\
\hline feet per second $(\mathrm{ft} / \mathrm{sec})$ & 0.3048 & meters per second $(\mathrm{m} / \mathrm{sec})$ \\
\hline
\end{tabular}

Vertical coordinate information is referenced to the North American Vertical Datum of 1988 (NAVD 88). Horizontal coordinate information is referenced to the North American Datum of 1983 (NAD 83). Elevation, as used in this report, refers to distance above the vertical datum. 


\title{
Digital Tabulation of Stratigraphic Data from Oil And Gas Wells in Cuyama Valley and Surrounding Areas, Central California
}

\author{
By Donald S. Sweetkind, Shiera C. Bova, Victoria E. Langenheim, Lauren E. Shumaker, and Daniel S. Scheirer
}

\begin{abstract}
Stratigraphic information from 391 oil and gas exploration wells from Cuyama Valley, California, and surrounding areas are herein compiled in digital form from reports that were released originally in paper form. The Cuyama Basin is located within the southeasternmost part of the Coast Ranges and north of the western Transverse Ranges, west of the San Andreas fault. Knowledge of the location and elevation of stratigraphic tops of formations throughout the basin is a first step toward understanding depositional trends and the structural evolution of the basin through time, and helps in understanding the slip history and partitioning of slip on San Andreas and related faults.
\end{abstract}

\section{Introduction}

Cuyama Valley is a rural agricultural area located about 55 kilometers $(\mathrm{km})$ north of Santa Barbara and approximately $65 \mathrm{~km}$ southwest of Bakersfield, California, in the southeasternmost part of the Coast Ranges of California (fig. 1). Cuyama Valley lies within the eastern part of the Coast Ranges, to the west of the San Joaquin Valley, and north of the west-trending Transverse Ranges (fig. 1).

Cuyama Valley sits at the intersection of four counties: the main portions of the valley are within Santa Barbara and San Luis Obispo Counties, regions near the headwaters of the Cuyama River lie in Ventura County, and a small eastern part of the valley lies within Kern County (fig. 1). The main economic activities in Cuyama Valley are ranching, agriculture, and oil and gas production. The Cuyama Basin has cumulative oil production plus reserves of about 290 million barrels of oil (Stanley, 1995; California Department of Conservation, 2009).

Topographic Cuyama Valley overlies and is part of a broader geologic domain referred to as the Cuyama Basin, which was a depocenter for marine and nonmarine sediments in Oligocene and Miocene time (Lagoe, 1984; 1987; Bazeley, 1988; Fritsche, 1988) and for a thick section of continental deposits in Pliocene and Pleistocene time (Vedder and Repenning, 1975; Ellis and others, 1993). The Cuyama Basin includes an area now occupied by the Caliente, Sierra Madre, and La Panza Ranges, Cuyama Valley, the Carrizo Plain, and the Cuyama Badlands (Lagoe, 1987) (figs. 1 and 2). In the Cuyama Basin, Oligocene extension and Miocene strike-slip faulting are overprinted and obscured by PliocenePleistocene thrust faults that bound the ranges which surround the current topographic valley (Calhoun, 1986; Davis and others, 1988) (fig. 2).

The Cuyama Basin lies to the west of the San Andreas fault in an area of transition between the strike-slip tectonics of the Coast Ranges to the northwest and the generally north-south compressive tectonics of the Transverse Ranges to the south (Calhoun, 1986; Davis and others, 1988) (figs. 1 and 2). 
Stratigraphic and structural reconstructions of the Cuyama Basin are central to interpretations of the Neogene tectonic evolution of the region, the translation and rotation of the Transverse Ranges, and the partitioning of slip amongst a system of faults to the north of the Transverse Ranges and to the west of the San Andreas fault. Subsurface geologic data in the area come from oil and gas wells from the major producing fields and from exploration drill holes scattered across the region. Knowledge of the location and elevation of stratigraphic tops of formations in this region is a first step toward understanding depositional trends and the structural evolution of the area through time (Lagoe, 1984; 1987).

In this data report, we compile stratigraphic information from oil and gas exploration and development wells from Cuyama Valley, Calif., and surrounding areas. The intent of this report is to compile, in digital form, drill hole stratigraphic information from diverse datasets and reports that have only been available in paper form. The digital data compiled here are suitable for incorporation within a geographic information system (GIS) and use in the construction of three-dimensional geologic framework models that can be used to address regional stratigraphic and structural questions. 


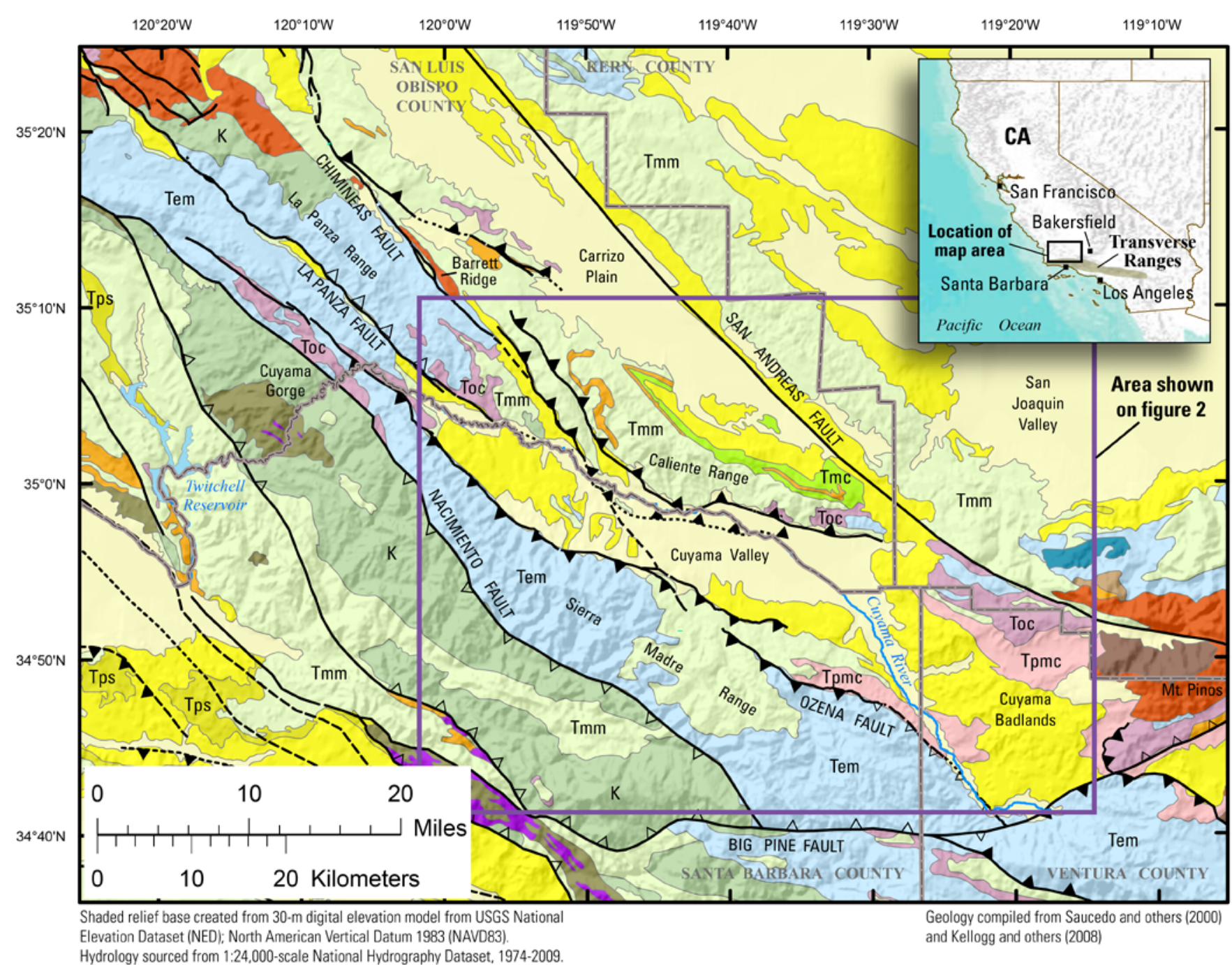

Hydrology sourced from 1:24,000-scale National Hydrography Dataset, 1974-2009.

Place names sourced from USGS Geographic Names Information System,

1974-2009. Albers Projection, NAD83

EXPLANATION

\begin{tabular}{|c|c|}
\hline & Quaternary sediments \\
\hline & $\begin{array}{l}\text { Quaternary and Pliocene } \\
\text { sediments }\end{array}$ \\
\hline Tps & Pliocene sediments \\
\hline Tpmc & $\begin{array}{l}\text { Pliocene and Miocene } \\
\text { continental rocks }\end{array}$ \\
\hline & Tertiary volcanic rocks \\
\hline Tmc & Miocene continental rocks \\
\hline Tmm & Miocene marine rocks \\
\hline Toc & Oligocene continental rocks \\
\hline
\end{tabular}

\begin{tabular}{|c|c|}
\hline Tem & Eocene marine rocks \\
\hline K & Cretaceous marine rocks \\
\hline & Mesozoic granitic rocks \\
\hline & Mesozoic Franciscan Complex \\
\hline & $\begin{array}{l}\text { Serpentinite within } \\
\text { Franciscan Complex }\end{array}$ \\
\hline & $\begin{array}{l}\text { Mesozoic and Paleozoic } \\
\text { ultramafic rocks }\end{array}$ \\
\hline & $\begin{array}{l}\text { Paleoproterozoic } \\
\text { granitic gneiss and } \\
\text { Paleocene Pelona Schist }\end{array}$ \\
\hline & Water \\
\hline
\end{tabular}

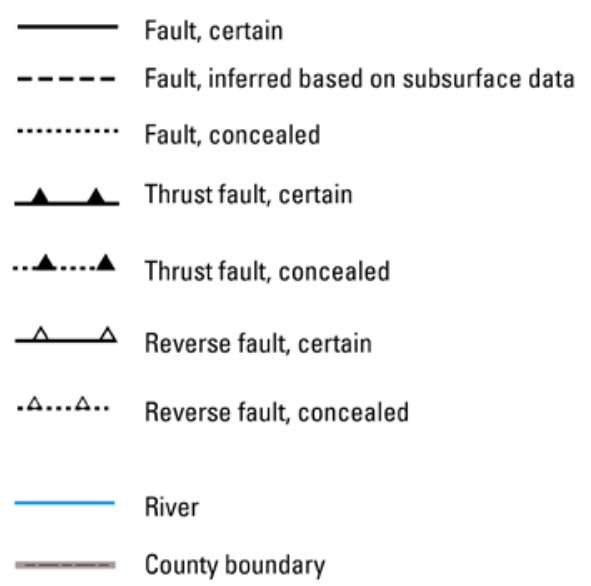

Figure 1. Generalized geologic map of the Cuyama Basin and surrounding region. 


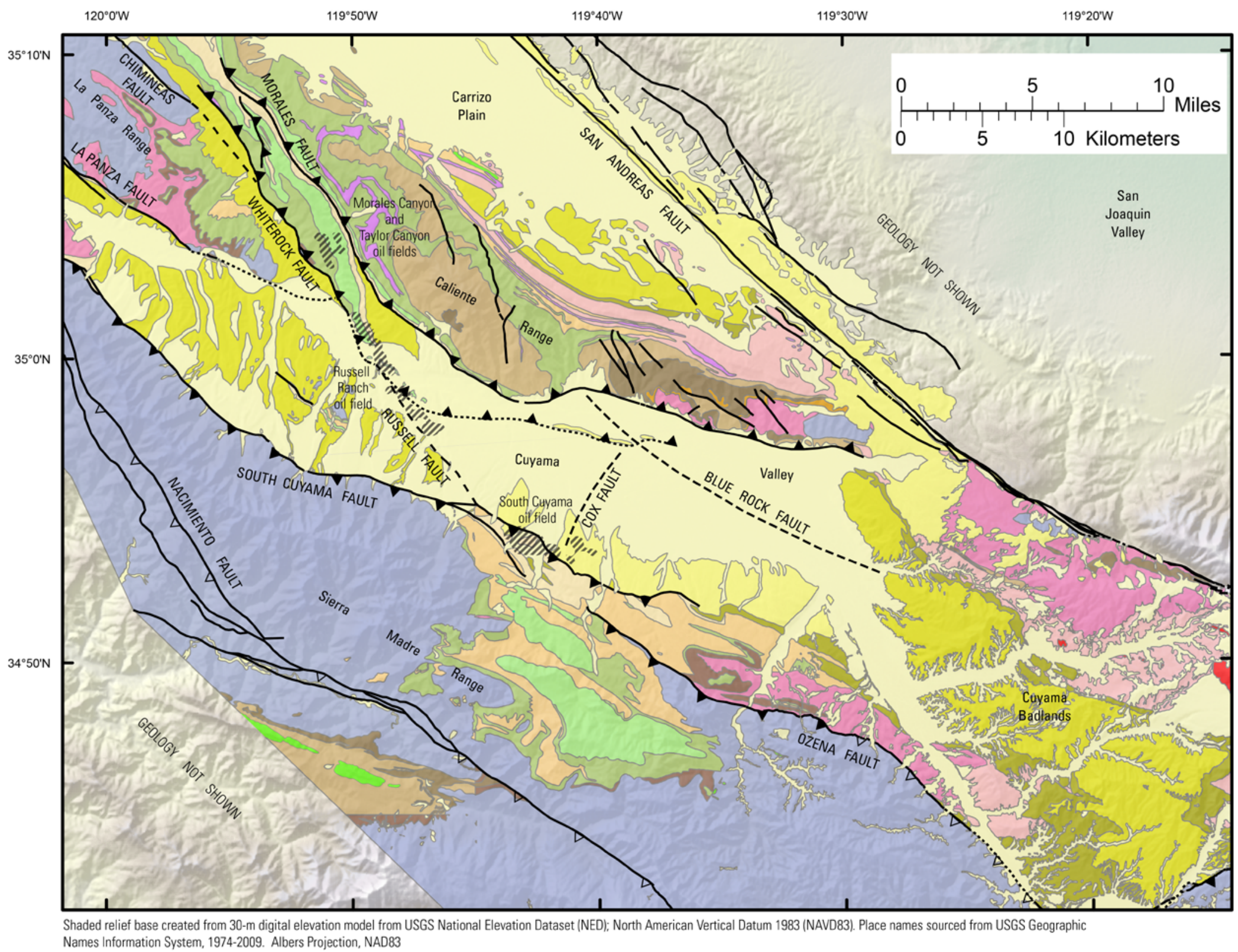

Figure 2. Geologic map of Cuyama Valley and surrounding ranges. 


\section{EXPLANATION}

[Geology compiled from Dibblee, 1972; Graham and others, 1999; and Kellogg and others, 2008]

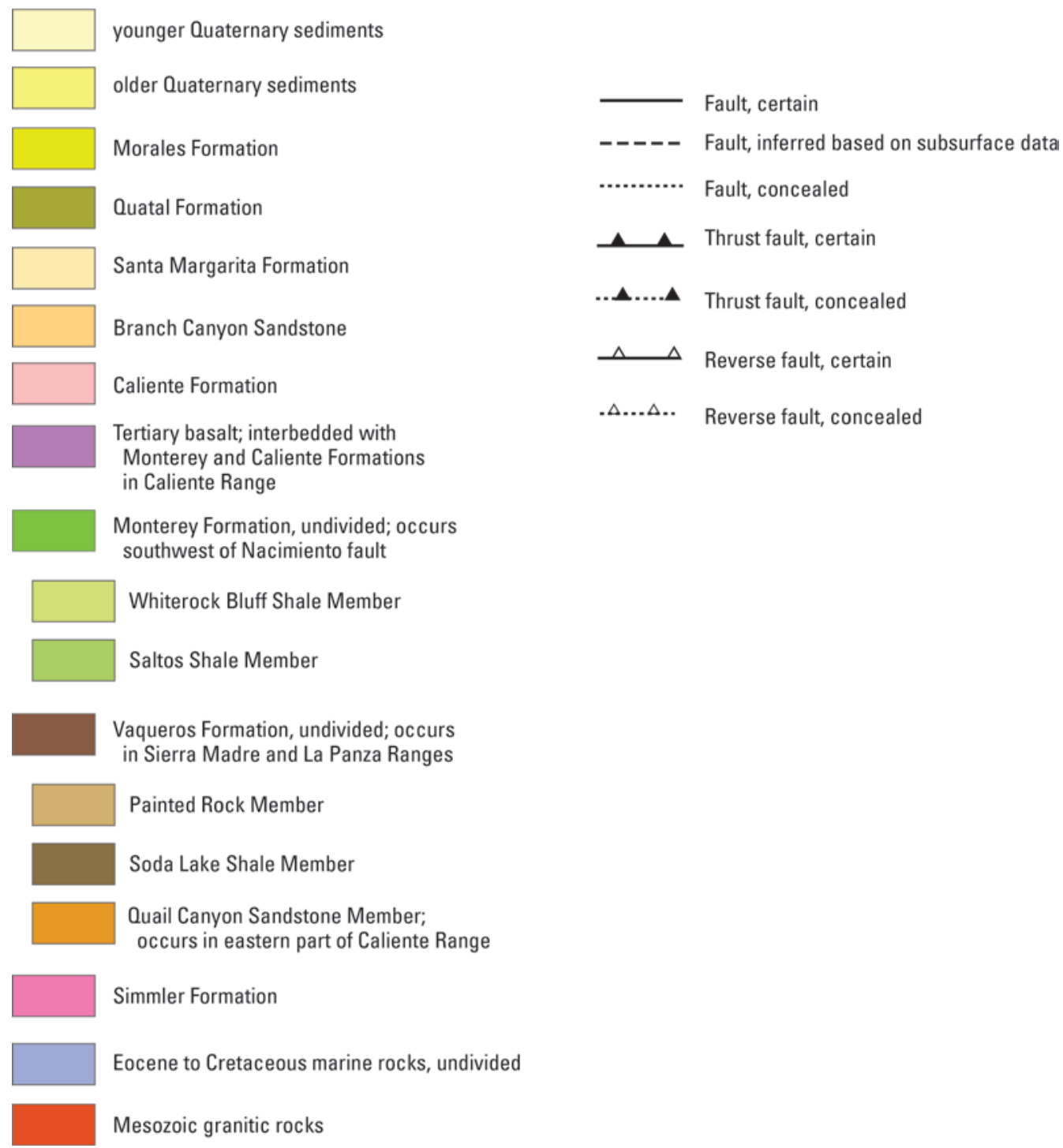

Figure 2-Continued. Geologic map of Cuyama Valley and surrounding ranges.

\section{Geologic Setting}

\section{Stratigraphy}

Cuyama Valley is underlain by a sequence of unconsolidated to partly consolidated nonmarine deposits including Pleistocene to Holocene alluvial and fluvial deposits and the underlying Pliocene and Pleistocene Morales Formation (Upson and Worts, 1951; Hill and others, 1958; Dibblee, 1982; DeLong and others, 2008; Kellogg and others, 2008). These deposits overlie an Upper Cretaceous to Neogene succession of consolidated marine and nonmarine sedimentary rocks, which themselves overlie crystalline granitic and gneissic rocks (Hill and others, 1958; Schwade and others, 1958; Lagoe, 1987) (figs. 2 and 3). This general stratigraphic succession is exposed in the La Panza Range and dips to the southeast towards Cuyama Valley (fig. 1). 


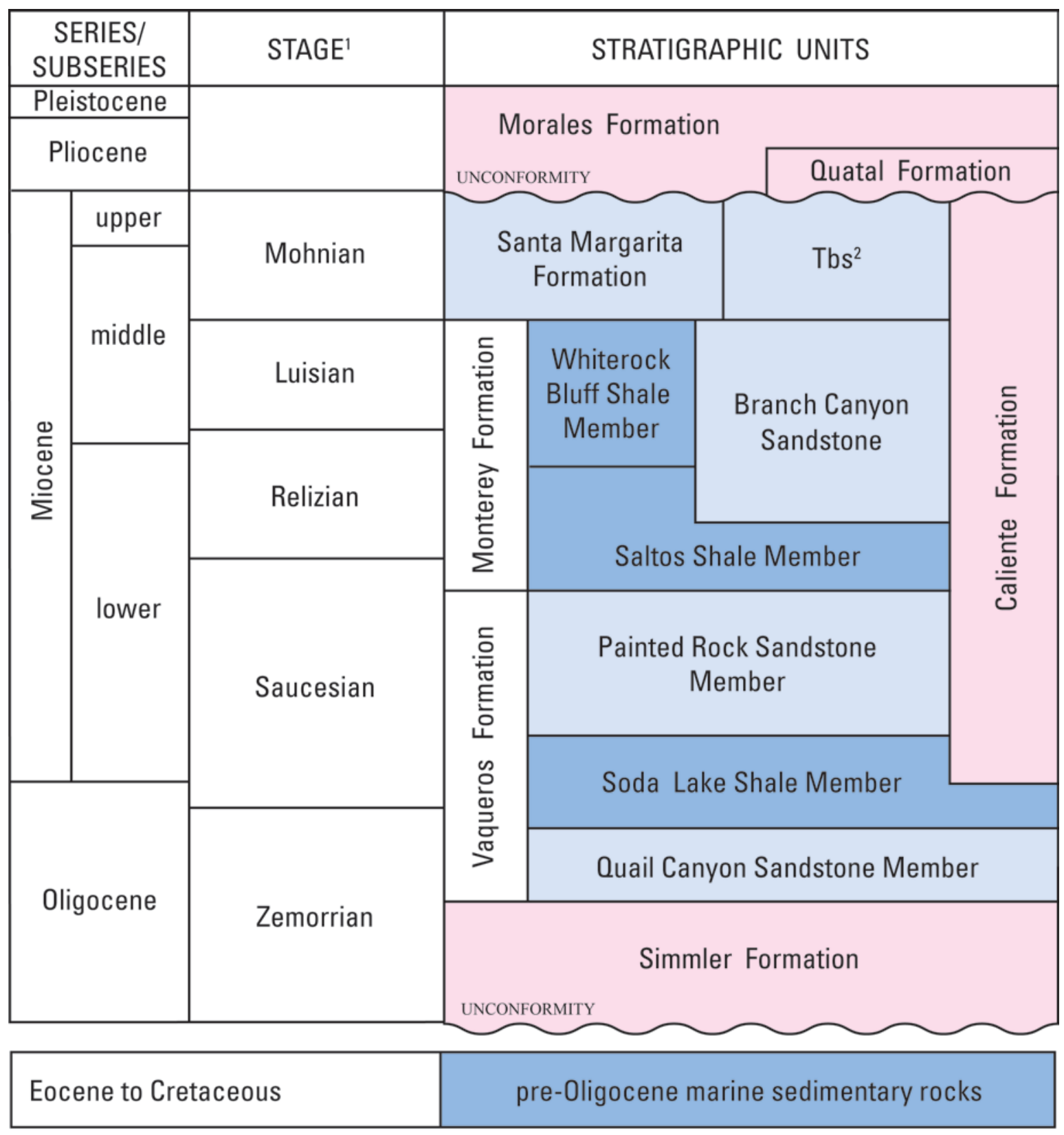

\section{Cretaceous and Paleoproterozoic granite and granitic gneiss basement rocks}

${ }^{1}$ California benthic foraminiferal stages (Kleinpell, 1938); ages after Prothero (2001).

${ }^{2}$ Santa Margarita Formation and Branch Canyon Sandstone, undivided.

\section{EXPLANATION}

\begin{tabular}{|c|c|}
\hline Shallow marine rocks & Continental sedimentary rocks \\
\hline Deep marine rocks & Crystalline basement rocks \\
\hline
\end{tabular}

Figure 3. Generalized stratigraphy of the Cuyama Basin. Modified from Lagoe (1987). 
The Cuyama Basin is part of the Salinian block, a structural block underlain by granitic and granitic gneiss basement rocks, in contrast to adjacent structural blocks that are characterized by basement rocks consisting of Franciscan Complex, Jurassic ophiolite, and upper Mesozoic forearc deposits (Reed and Hollister, 1936; Dibblee, 1973; Graham, 1978). The Salinian block, which extends northward to Monterey, Calif., is bounded on the northeast by the San Andreas fault, on the southwest by the Nacimiento fault, and is separated from the Transverse Ranges to the south by the Big Pine fault (fig. 1). Several wells in Cuyama Valley intercept granitic or gneissic rocks at depth, as expected for wells within the Salinian block.

Upper Cretaceous to Eocene marine strata overlie crystalline basement in the La Panza Range (Chipping, 1972; Howell and others, 1977) and regionally dip to the southeast (fig. 1). In the La Panza Range, this sequence is as much as 9,000 meters (m) thick (Chipping, 1972; Dibblee, 1973); thickness beneath Cuyama Valley is not defined because few wells completely penetrate this part of the section. The Paleocene Pattiway Formation crops out in the southeastern part of the Caliente Range (Vedder and Repenning, 1975; Kellogg and others, 2008) (fig. 2); these rocks may be correlative with the preOligocene marine strata intercepted in the subsurface, but this correlation was not examined. In this report, all pre-Oligocene sedimentary rocks are identified as $\mathrm{TKu}$ : pre-Oligocene marine sedimentary rocks, undivided (appendix 1).

Oligocene continental strata of the Simmler Formation unconformably overlie Upper Cretaceous to Eocene marine strata and Paleoproterozoic and Cretaceous crystalline basement. The Simmler consists of conglomerate and sandstone redbeds and rare interbedded basalts (Hill and others, 1958; Bartow, 1978). This unit varies widely in thickness from as much as $900 \mathrm{~m}$ in the subsurface to entirely missing in some areas. The Simmler Formation crops out to the northwest of Cuyama Valley in the Cuyama Gorge, to the north of the valley in the Caliente Range, and to the west and northeast of the Cuyama Badlands (figs. 1 and 2). A coarse, conglomeratic facies of the Simmler Formation is common in the southeastern La Panza Range and in the Cuyama Gorge to the west of Cuyama Valley (fig. 1) and is encountered in the subsurface. The unit is interpreted to have been deposited in local basins bounded by normal faults, with coarse, conglomeratic facies deposited adjacent to Oligocene-age normal faults (Bartow, 1978; Ballance and others, 1983).

Late Oligocene and Miocene sedimentation in the Cuyama Basin consisted of two transgressiveregressive cycles (Fritsche, 1988). The first transgression began with the deposition of the shallowwater Quail Canyon Sandstone Member of the Vaqueros Formation, followed by abrupt deepening of the basin and deposition of the Soda Lake Shale Member of the Vaqueros Formation (Dibblee, 1973; Fritsche, 1988; Bartow, 1990; 1995) (figs. 3 and 4). Deposition of the overlying regressive, shallowwater Painted Rock Sandstone Member of the Vaqueros Formation marked the end of the first cycle (Lagoe, 1987; Fritsche, 1988; Bartow, 1990). The Soda Lake Shale and Painted Rock Sandstone Members show abrupt changes in thickness and electric log character as a result of facies variations within local depocenters in the basin (Bartow, 1978; 1990), at least some of which were controlled by offset on the then-active Russell fault (Yeats and others, 1989). The second transgressive cycle includes the bathyal marine mudstones and turbiditic sandstones of the Saltos Shale Member of the Monterey Formation, overlain in the northern and western part of the basin by the shallowing-upward sequence of upper-bathyal Whiterock Bluff Shale Member of the Monterey Formation and the shallow marine sandstones of the Santa Margarita Formation (Lagoe, 1984; 1987; Fritsche, 1988) (figs. 3 and 4). 


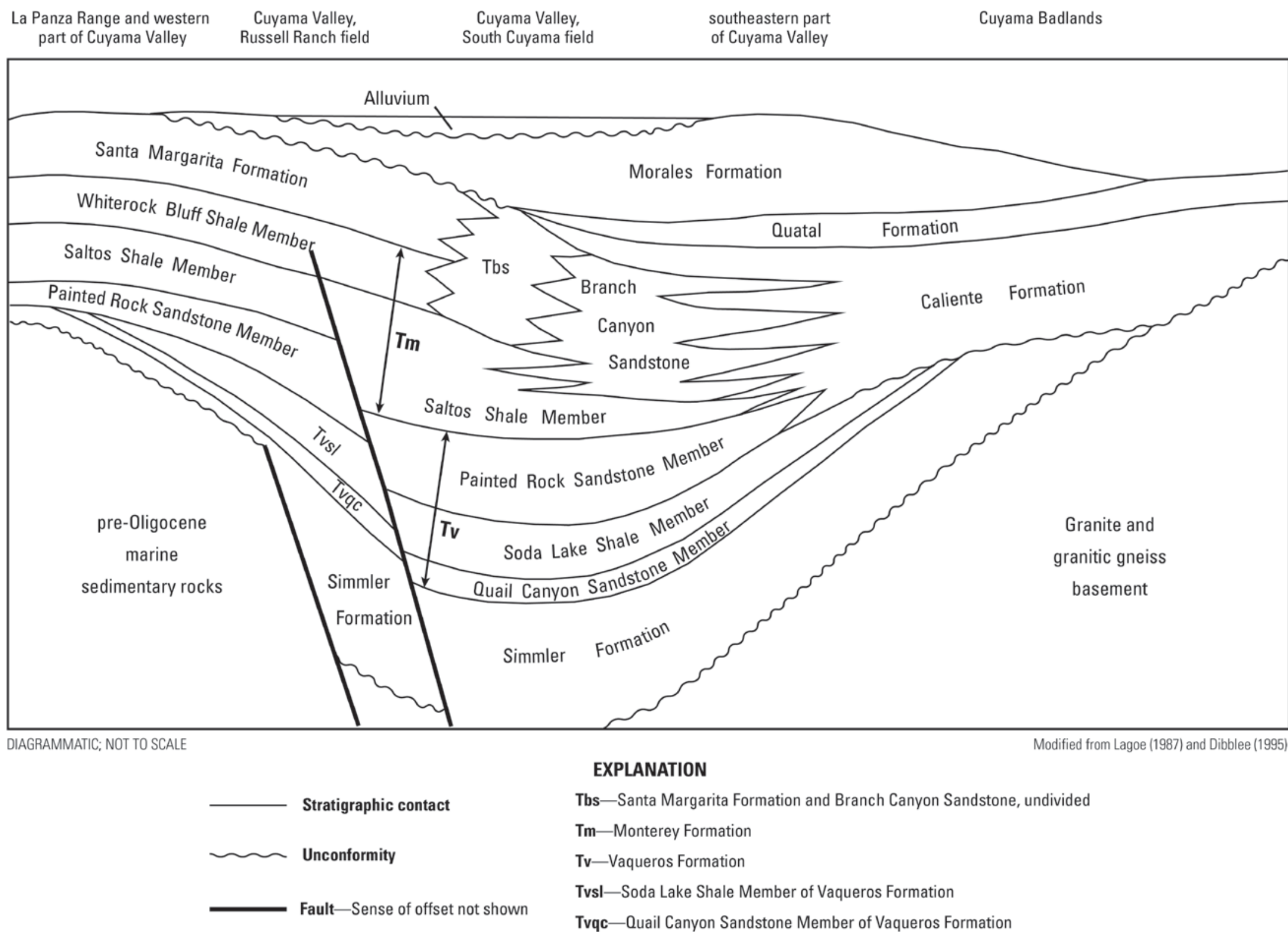

Figure 4. Diagrammatic northwest-southeast stratigraphic section across the Cuyama Basin. Modified from Lagoe (1987) and Dibblee (1995). 
The Miocene subsurface stratigraphic sequence in the Cuyama Basin grades from predominantly marine strata in the west to mainly nonmarine strata in the east (Vedder, 1973; Lagoe, 1987) (fig. 4). The Painted Rock Sandstone Member of the Vaqueros Formation interfingers eastward with the nonmarine Caliente Formation that was deposited on the eastern margin of the basin (Hill and others, 1958; Clifton, 1981). The Saltos Shale Member of the Monterey Formation is in part overlain by and interfingers with the Branch Canyon Sandstone, a near-shore, shallow marine sandstone that prograded from east to west (Perri and Fritsche, 1988). The Branch Canyon Sandstone, in turn, grades eastward into the nonmarine Caliente Formation (Hill and others, 1958; Dibblee, 1973; Vedder, 1973; Lagoe, 1987) (fig. 4). During the middle to late Miocene, the fluvial Caliente Formation was deposited in the present-day Cuyama Badlands at the same time the marine Saltos Shale Member of the Monterey Formation and Branch Canyon Sandstone were being deposited to the west (Lagoe, 1987). The shallowmarine Santa Margarita Formation overlies both the Branch Canyon Sandstone and Monterey Formation and marks the end of marine deposition in the Cuyama Basin (Hill and others, 1958).

The Miocene strata are overlain by the Pliocene lacustrine Quatal Formation and the Pliocene to Pleistocene nonmarine deposits of the Morales Formation, themselves overlain by younger alluvial deposits (fig. 4). The Morales Formation is a fluvial deposit of gravelly arkosic sand that is up to 1,400 m thick (Hill and others, 1958; Ellis and others, 1993); the unit is widely exposed in the Cuyama Badlands (fig. 2) and underlies younger alluvial deposits beneath Cuyama Valley (Nevins, 1982; Schwing, 1984; Spitz, 1986). In this report, we make no attempt to separate the Morales Formation from overlying alluvial deposits, because they are lithologically similar.

\section{Structure}

The Cuyama Basin has had a long and variable history of deformation that has greatly influenced the thickness and depositional patterns of the sedimentary units and resulted in the juxtaposition of diverse formations across faults. An Oligocene phase of extensional faulting occurred on faults with present-day, west-to-northwest trends including the La Panza (Bartow, 1978; Ballance and others, 1983), Ozena (Blake, 1982), and Blue Rock (Dibblee, 1982; Calhoun, 1986) faults (fig. 2). These faults have crystalline basement and Eocene sedimentary rocks on their southwestern, upthrown sides and have resulted in localized deposition of Simmler Formation conglomerates on their northeastern, downthrown sides (Bartow, 1978; Blake, 1982; Ballance and others, 1983).

In Miocene time, deformation changed from extension to predominantly right-lateral strike slip motion. The Russell strike-slip fault (fig. 2), known only from the subsurface of Cuyama Valley, has from 26 to $29 \mathrm{~km}$ of right-lateral slip in the northwest part of Cuyama Valley (Yeats and others, 1989). On the basis of decreasing offset of progressively younger beds, Yeats and others (1989) inferred that the Russell fault was most active in the early Miocene (23 to $19 \mathrm{Ma}$ ), with decreasing slip rates to $4 \mathrm{Ma}$. Isopach maps of the Vaqueros and Monterey Formations show that the Russell fault influenced depositional thickness trends of these units (Lagoe, 1981; 1984; Calhoun, 1986; Spitz, 1986). Syndepositional normal faults with present-day north and northeast trends, such as the Cox fault southeast of the South Cuyama field (fig. 2), resulted in large thickness changes within the Saltos Shale Member of the Monterey Formation (Lagoe, 1981; 1984; Calhoun, 1986; Spitz, 1986).

During Pliocene to Pleistocene time, deformation of Cuyama Valley changed to a predominantly compressional mode, resulting in the formation of folds and thrust faults (Davis and others, 1988). As a result of compression, Cuyama Valley is currently a downfolded structural basin bounded to the north and south by thrust faults. Miocene rocks of the Caliente Range to the north of Cuyama Valley are being thrust southward over Quaternary alluvium along the Morales and Whiterock thrusts; similar-aged rocks in the Sierra Madre Range to the south of Cuyama Valley are being thrust northward over Quaternary 
alluvium on the South Cuyama fault (Vedder and Repenning, 1975; Davis and others, 1988; Kellogg and others, 2008) (fig. 2). Some present-day reverse faults, including the La Panza and Ozena faults (fig. 2), are reactivated Oligocene extensional faults (Bartow, 1978; Balance, 1983; Ellis, 1994).

\section{Data Compilation Methodology}

Below we describe specific aspects of the datasets used and particular details of location and stratigraphic issues we faced during data compilation.

\section{Well Location}

Well locations (fig. 5) were obtained in a digital well location database from the California Department of Conservation, Division of Oil, Gas and Geothermal Resources (CA DOGGR) (Accessed February 2013, at http://www.conservation.ca.gov/dog/maps/Pages/GISMapping2.aspx/). Oil and gas exploration holes in the database, and in this report, are referenced by API well number, a unique, permanent, numeric identifier assigned to each well drilled for oil and gas in the United States. Two wells listed in appendix 1 do not have assigned API numbers. The information contained in the database includes API well number; operator; lease name and well number; section, township, and range; and latitude and longitude. Most of the oil wells in Cuyama Valley are clustered within the two fields with historic and continuing production - the Russell Ranch oil field (Burgan, 1949; Barger and Zulberti, 1952) and the South Cuyama oil field (Zulberti, 1954) — and two smaller fields to the northwest, the Morales Canyon and Taylor Canyon fields (Calhoun, 1986; Stanley, 1995) (figs. 2 and 5). Production wells in these fields are spaced very closely; selected wells from these fields are compiled in this report to represent geologic conditions in the vicinity of the producing fields. Exploratory wells were drilled outside of the fields at widely scattered locations across Cuyama Valley (fig. 5). Data from every one of these exploratory wells were compiled for this study. Ultimately, data from 391 oil and gas exploration wells were compiled for subsurface stratigraphic information.

\section{Sources of Well Data}

Well stratigraphic data were obtained from various sources including published information and online data from the CA DOGGR, information found in paper records held by the CA DOGGR, several published theses, and electric logs (fig. 5). Sources of data are described below. 


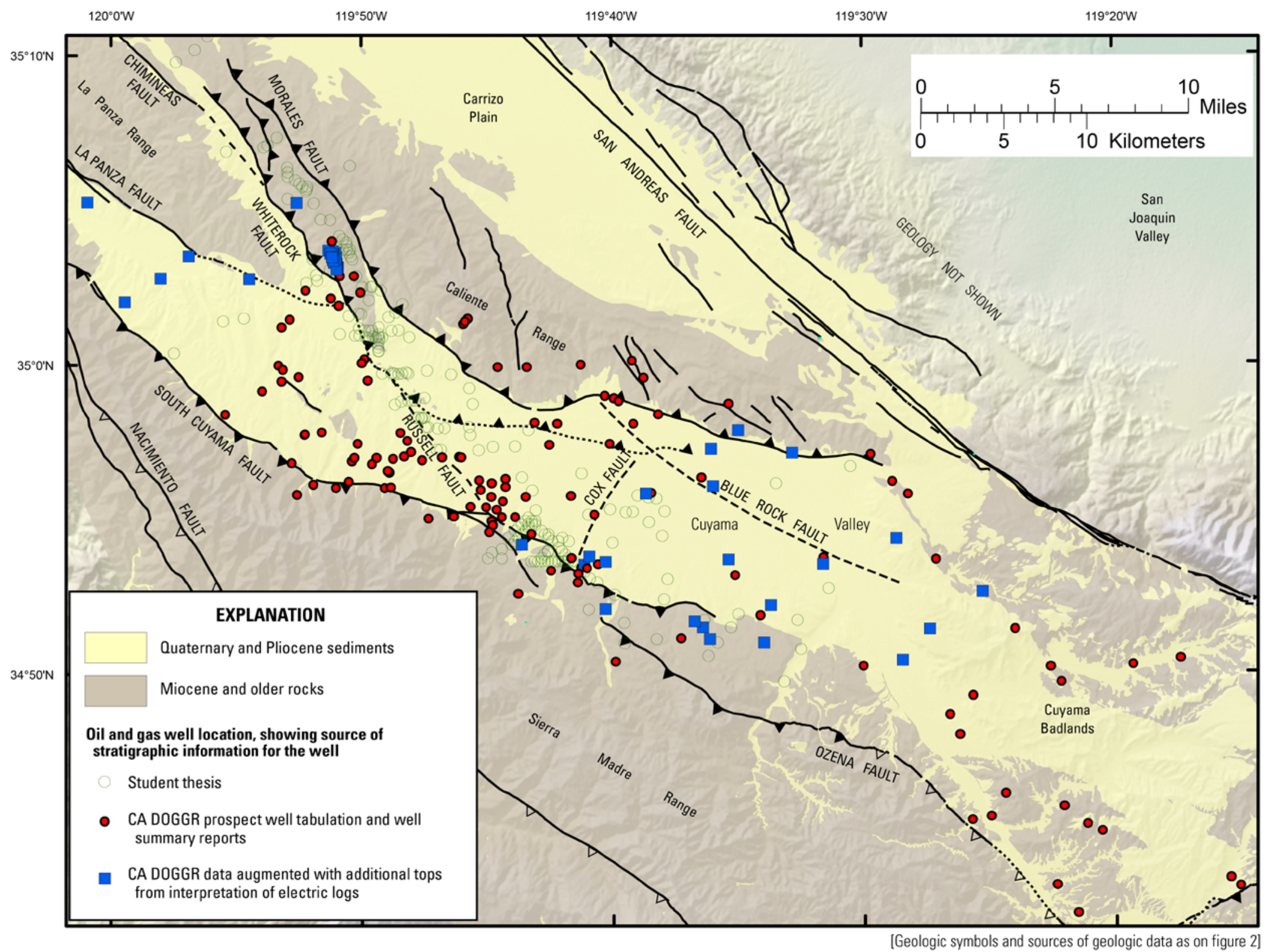

Figure 5. Map showing location of oil and gas wells in Cuyama Valley and surrounding areas, symbolized by source of subsurface stratigraphic data. 


\section{Prospect Well Reports}

The CA DOGGR routinely publishes information from exploratory drilling throughout California. The drilled depths to the tops of the formations penetrated in the well are compiled by the state from records submitted by oil companies. A summary table of data for oil and gas prospect wells drilled through 1963 and year-by-year tables for wells drilled between 1960 and 1980 was published in 1982 (California Department of Conservation, Division of Oil and Gas, 1982). Data on wells from 1980 to the present are published yearly in the Annual Report of the State Oil and Gas Supervisor (California Department of Conservation, 2009); these reports are available online from the CA DOGGR (Accessed February 2013, at http://www.conservation.ca.gov/dog/pubs_stats/annual_reports/Pages/annual_reports.aspx/).

\section{Well Summary Reports}

The CA DOGGR maintains at its offices complete records of all wells drilled in a particular district. This information includes copies of legal filings of intention to drill a new well, well summary reports and drilling history, notice of intention to abandon, and other paperwork associated with operation and closure of oil and gas wells. These paper files often contain geologic annotation that give depths to geologic formations; these data can differ from, or supplement, data released in the prospect well records. We obtained well records for all wells of interest in Cuyama Valley region and transcribed to digital form all geologic annotations found in these files.

\section{Student Theses}

In the 1980s, four M.S. theses (Nevins, 1982; Schwing, 1984; Calhoun, 1986; Spitz, 1986) and one Ph.D. dissertation (Ellis, 1994) were produced at Oregon State University under the guidance of Professor Robert Yeats (fig. 6). These works, and subsequent derivative publications (Schwing, 1982; Ellis and Spitz, 1987; Yeats and others, 1989), discussed the subsurface geology of Cuyama Valley and focused on the mapping of subsurface formations using subsurface data from oil exploration holes, in particular from electric logs. Each thesis contained several stratigraphic cross sections that correlated subsurface formations across the valley (fig. 6). Formation tops interpreted from electric-log correlations were compiled from the thesis cross sections and added to the digital database. These sections served as a starting point for the electric-log interpretations of formation tops in this study. 


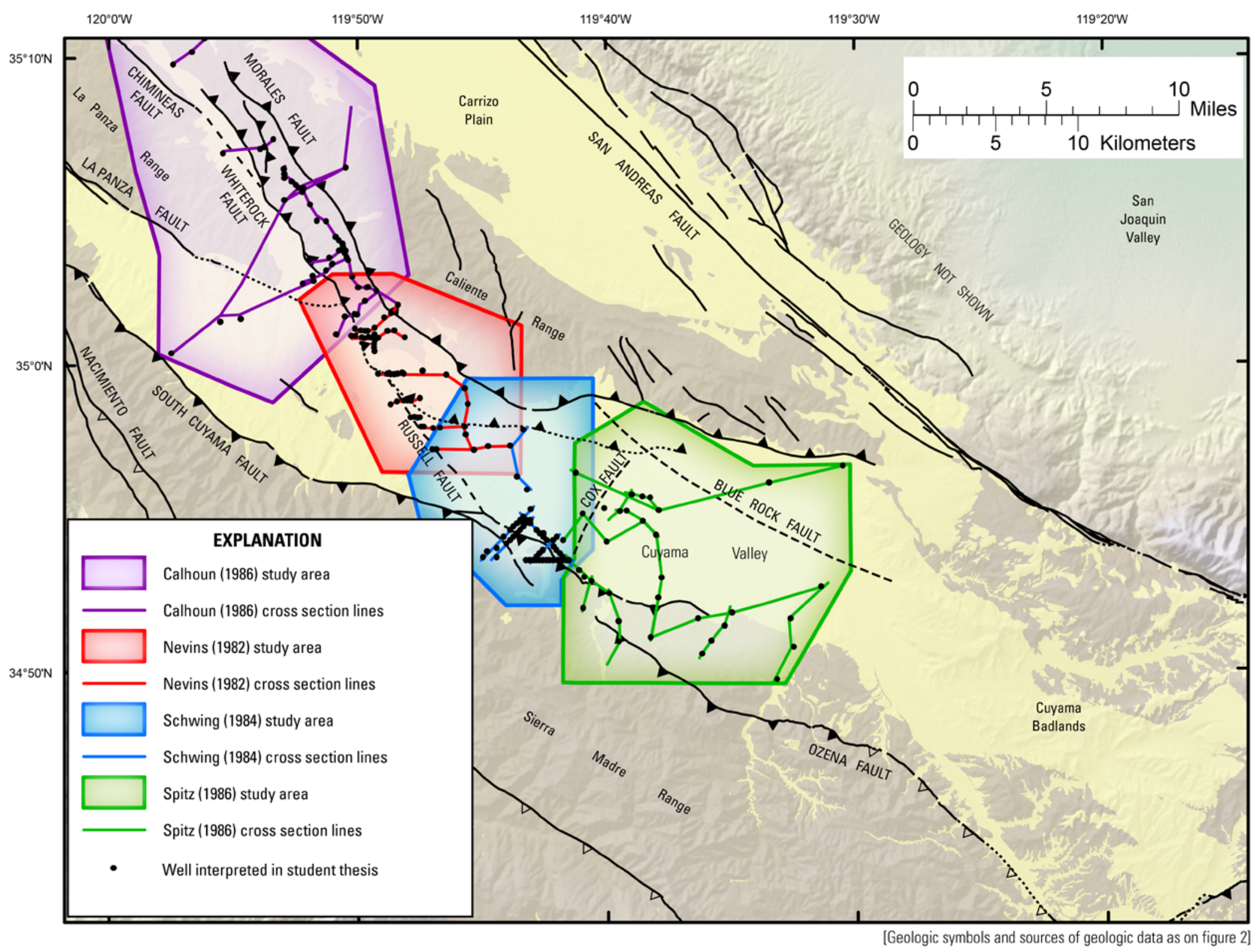

Figure 6. Map showing location of student thesis areas and subsurface cross sections in Cuyama Valley. 


\section{Electrical, Sonic, and Density Logs}

The CA DOGGR maintains on file paper copies of electric logs for most of the oil and gas exploration holes in Cuyama Valley. Initially, electric logs were obtained directly from the CA DOGGR district office in Santa Maria, Calif., by physically scanning paper copies of the logs. The CA DOGGR has subsequently made some of the electric logs available online (Accessed February 2013, at http://owr.conservation.ca.gov/WellSearch/WellSearch.aspx/).

The electric logs serve as an important data source for the interpretation of formation tops and assessing the validity of stratigraphic information from other sources. In addition, occasionally these logs include handwritten annotations indicating interpreted formation tops; these written annotations were also transcribed to digital files. Figure 7 shows the location of three wells with example electric logs typical of wells in the study area. Figure 8 shows the electric logs from these example wells which come from different stratigraphic and structural settings within the basin; specific aspects of these logs that relate to interpretation of stratigraphic tops are discussed in a subsequent section.

An electric log typically consists of a spontaneous potential, or SP, curve placed alongside one or more resistivity curves (fig. 8); these logs are obtained simultaneously from measurement equipment in the borehole. Taken together, these logs are often referred to as an electrical survey or ES log. Many of the oil and gas exploration wells in Cuyama Valley were drilled in the 1940s and 1950s (Stanley, 1995) when these electric logs were commonly the only geophysical logs run downhole. These logs are valuable for correlation of geologic units between wells, determination of bed thickness, distinguishing porous and nonporous rocks in shale-sandstone sequences, and identifying the location of fresh waterbearing beds (Keys and MacCary, 1971). The SP log measures small differences in electrical potential, in millivolts, between a downhole moveable electrode and an earth-surface connection. This potential is not deliberately introduced during logging but instead results from variations in currents that flow between the shaly and sandy rock layers in the presence of drilling mud, fluid in the borehole, and formation waters (Keys and MacCary, 1971; Johnson and Pile, 2002). Resistivity logs measure the inherent resistivity of the formations penetrated by the borehole in response to currents generated by the borehole tool. Typically, resistivity measurements are made with devices that contain multiple electrodes of varying spacing and give rise to multiple downhole resistivity curves (fig. 8). Shorter spacing between electrodes gives good vertical detail but records conditions near the borehole wall; longer electrode spacing reduces vertical resolution, but records formation conditions farther from the borehole that are less affected by drilling fluids (Keys and MacCary, 1971; Johnson and Pile, 2002). Resistivity curves are designated as normal or lateral logs depending on the specific arrangement of the electrodes. 


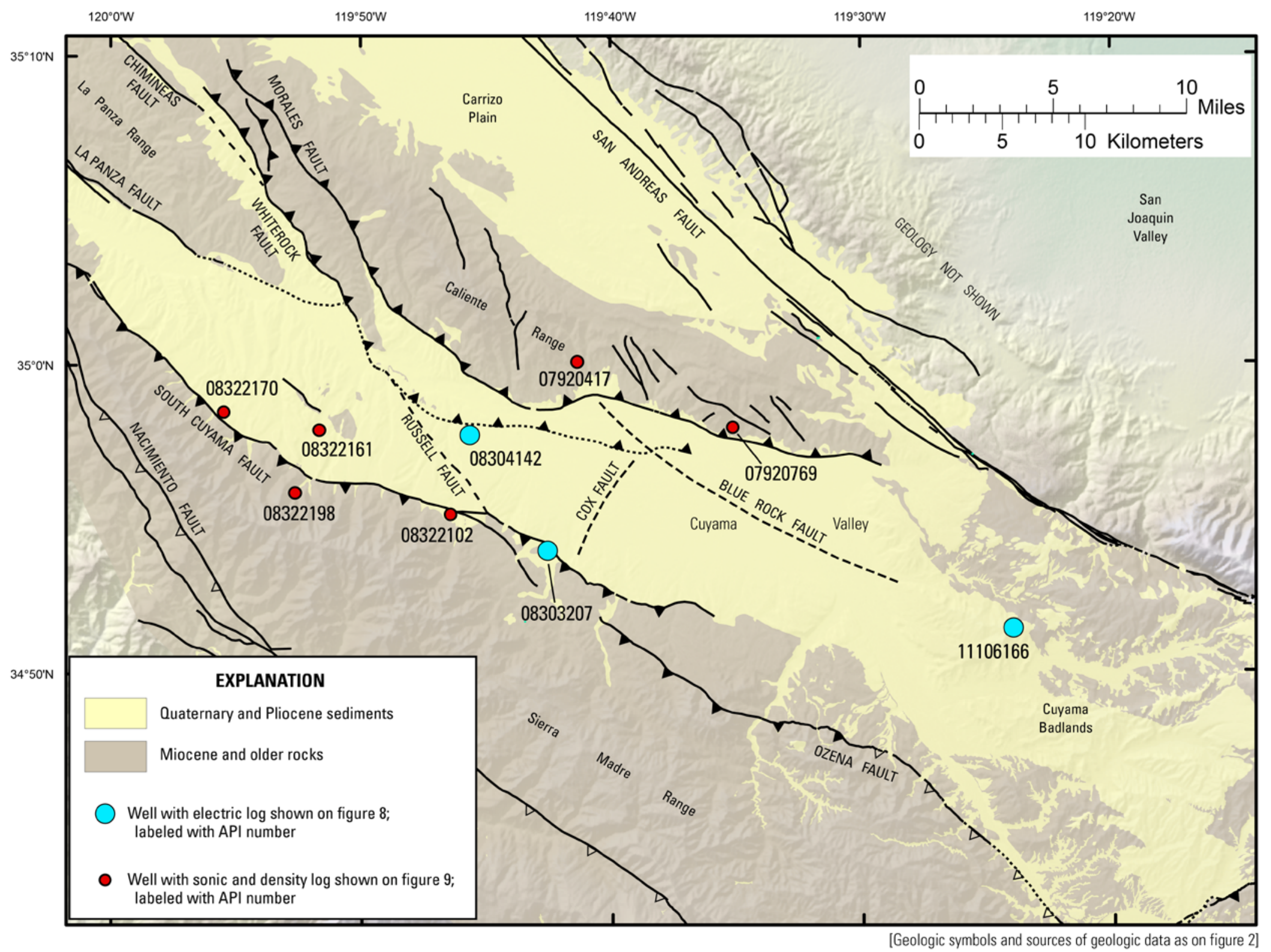

Figure 7. Map showing location of wells with example electric logs and wells with sonic and density logs in Cuyama Valley and surrounding areas. 
A

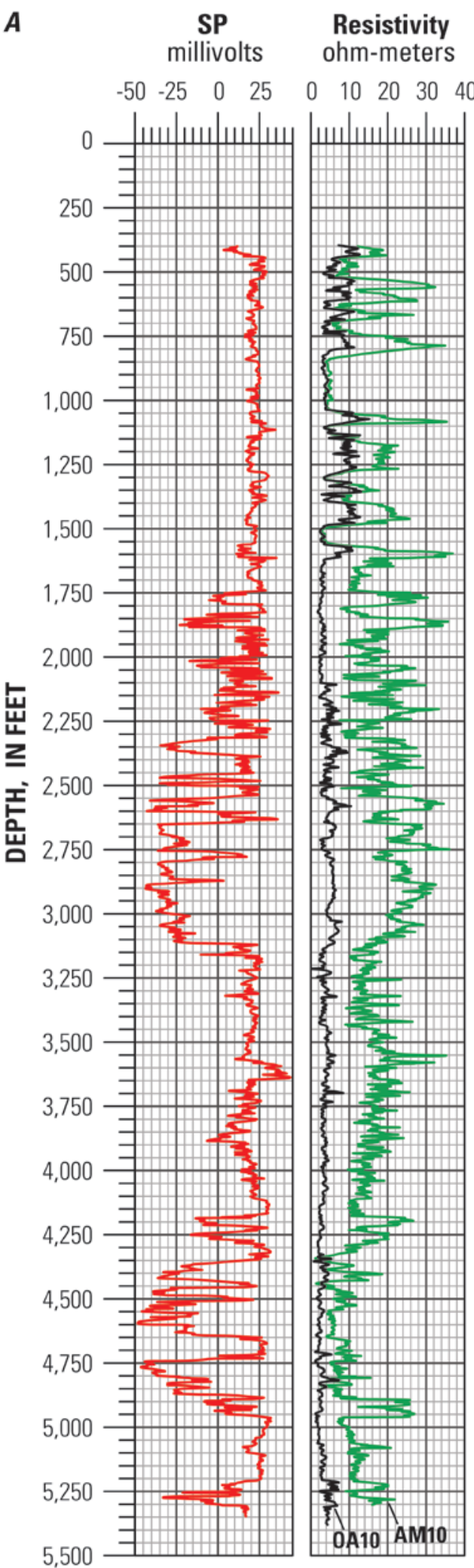

Well: Russell A 25-10

API: 08304142

Well location shown on figure 7.

\section{Explanation of curves on resistivity logs}

Morales

Formation

AM10 - Normal resistivity log; 10 -inch electrode spacing.

0A10 - Lateral resistivity log; 10 -foot electrode spacing.

Santa Margarita

Formation -

Branch Canyon

Sandstone,

undivided

Branch Canyon

Sandstone

Saltos Shale

Member

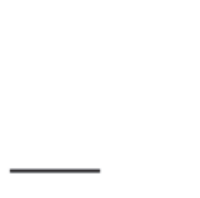

Painted Rock

Sandstone Member

Soda Lake

Shale Member

Quail Canyon

Sandstone Member

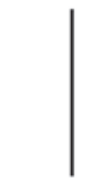

Monterey

Formation
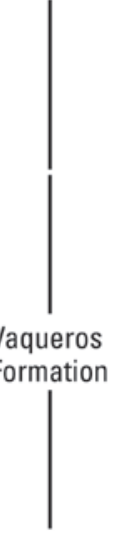

Figure 8. Representative electric logs from Cuyama Valley. A, Typical stratigraphic section from the Russell Ranch oil field. 
B

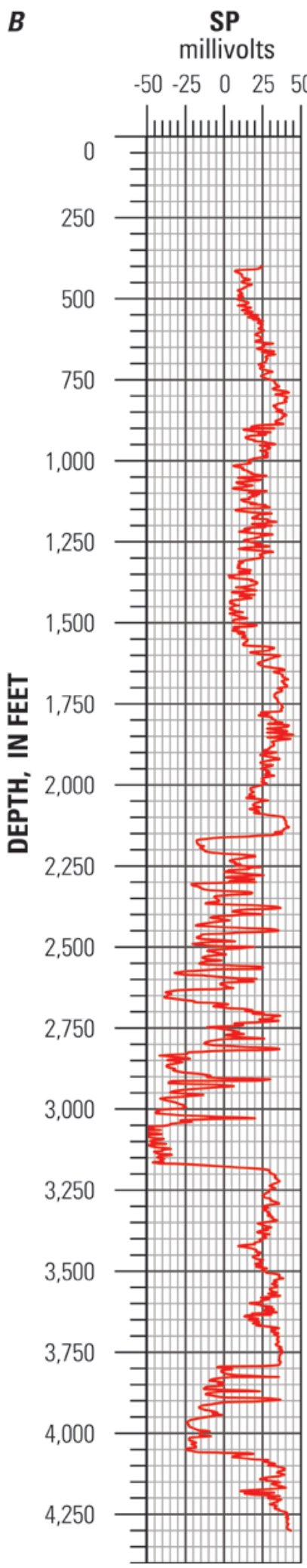

Resistivity

ohm-meters

$\begin{array}{llllll}0 & 10 & 20 & 30 & 40\end{array}$

|щишщшщш
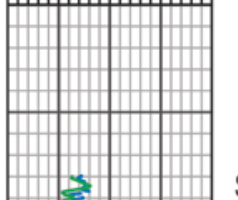

Formation above

South Cuyama

thrust fault
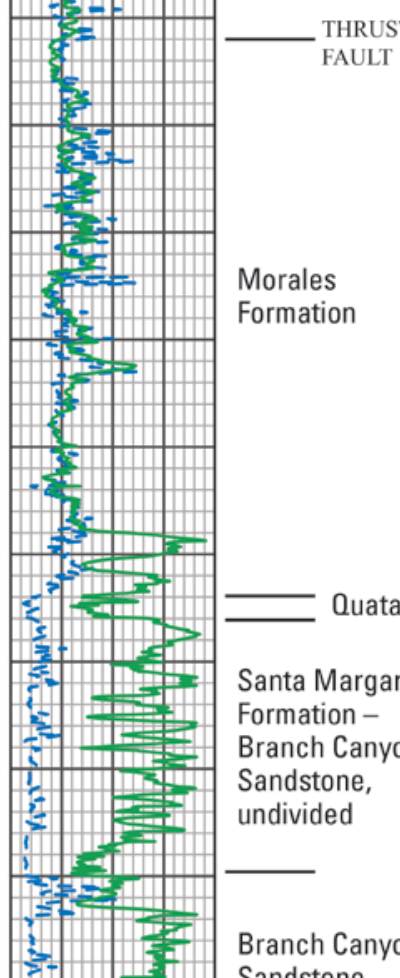

,

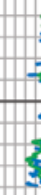

\section{,}

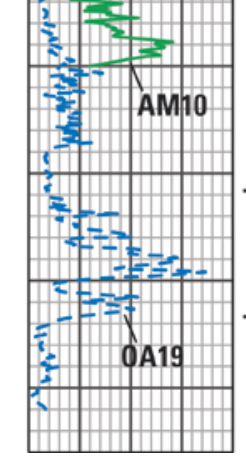

Well: South Cuyama Unit 18-31

API: 08303207

Well location shown on figure 7.

\section{Explanation of curves on resistivity logs}

AM10 - Normal resistivity log; 10 -inch electrode spacing.

\begin{tabular}{l|l} 
Morales & OA19 — Lateral resistivity log;
\end{tabular} Formation 19-foot electrode spacing.

Figure 8-Continued. Representative electric logs from Cuyama Valley. B, Thrust-faulted section from the South Cuyama oil field. 
C

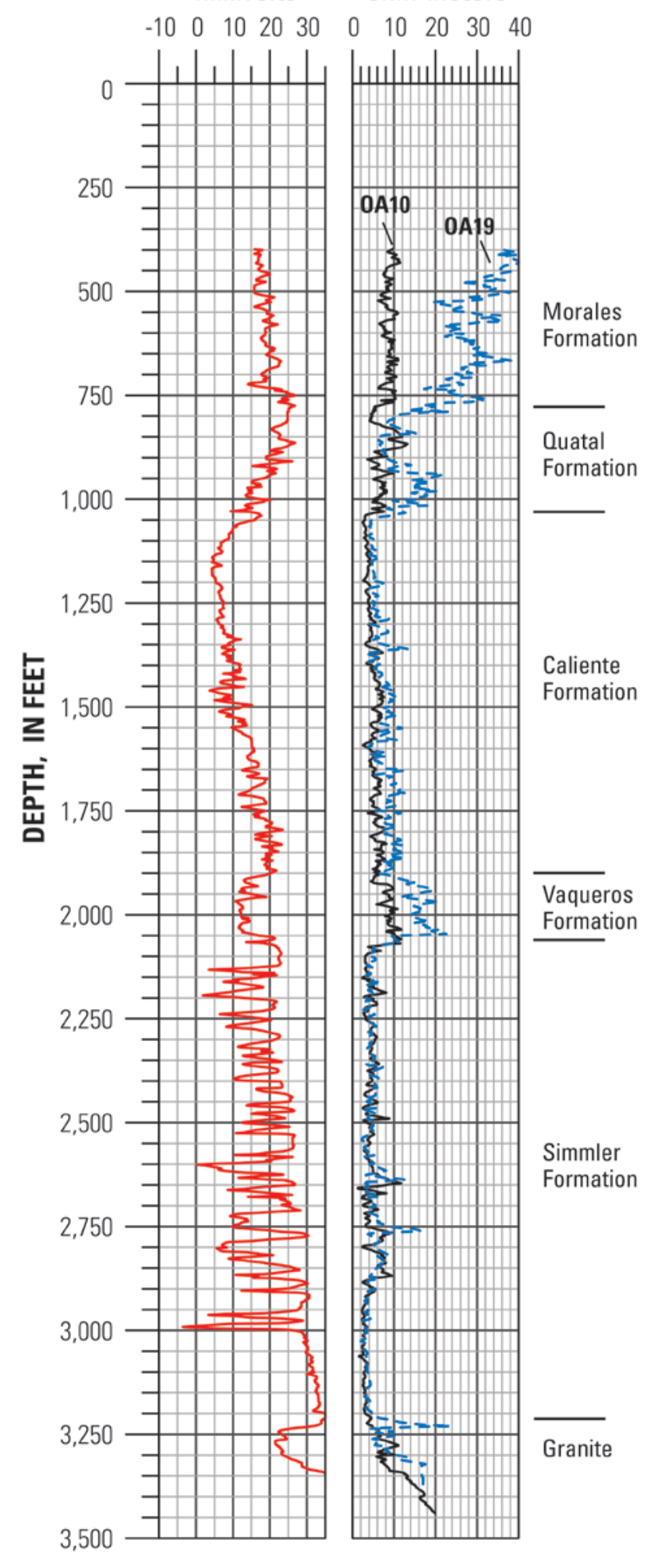

Well: Gillbergh A-2

API: 11106166

Well location shown on figure 7.

\section{Explanation of curves on} resistivity logs

0A10 - Lateral resistivity log; 10 -foot electrode spacing.

0A19 - Lateral resistivity log; 19-foot electrode spacing.

Figure 8-Continued. Representative electric logs from Cuyama Valley. C, Section dominated by continental rocks from the Cuyama Badlands 
Sonic velocity and density logs are also used to characterize the lithology and porosity of rocks. Sonic velocity and density are related physical properties. We purchased six sonic and four density logs from six wells in the broader Cuyama region (fig. 7 for location); two of the wells did not have density logs available. These logs were purchased as scanned images of paper originals, which we handdigitized. Sonic logs measure the time for a compressional sound wave in rock to travel between two depths in the well bore. Using scanned copies of the original sonic logs, we digitized interval transit times, in microseconds per foot, as a function of depth down the well and then converted the transit time to an interval velocity in feet per second. For the density logs, a gamma-gamma density logging tool was used, which employs a gamma-ray source and a pair of gamma-ray detectors. One detector measures only natural gamma rays from the formations surrounding the borehole, whereas the second detector receives both the natural gamma rays and those originating from the gamma-ray source that are scattered from the formations surrounding the borehole. The count rate from the second detector is modified by the count rate of the first detector, providing a density measurement that is corrected for the effects of natural gamma radiation produced in the formations. For the gamma-gamma density logs, we digitized from the scanned logs values of bulk density, in grams per cubic centimeter, as a function of depth down the well. Resultant sonic and density logs from six wells in Cuyama Valley and surrounding areas are shown in figure 9. 


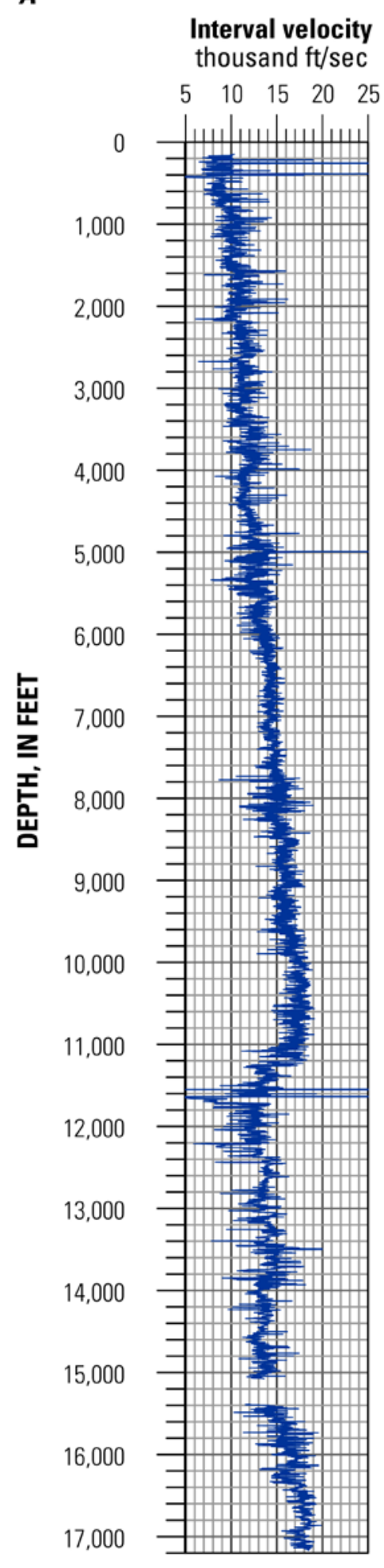

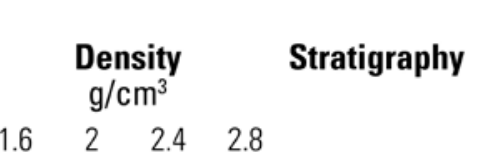
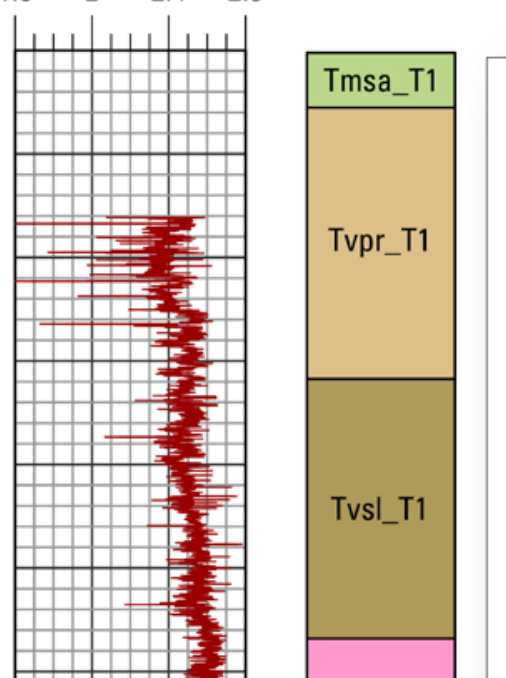

\begin{tabular}{|l|} 
Tvsi_T1 \\
\hline
\end{tabular}
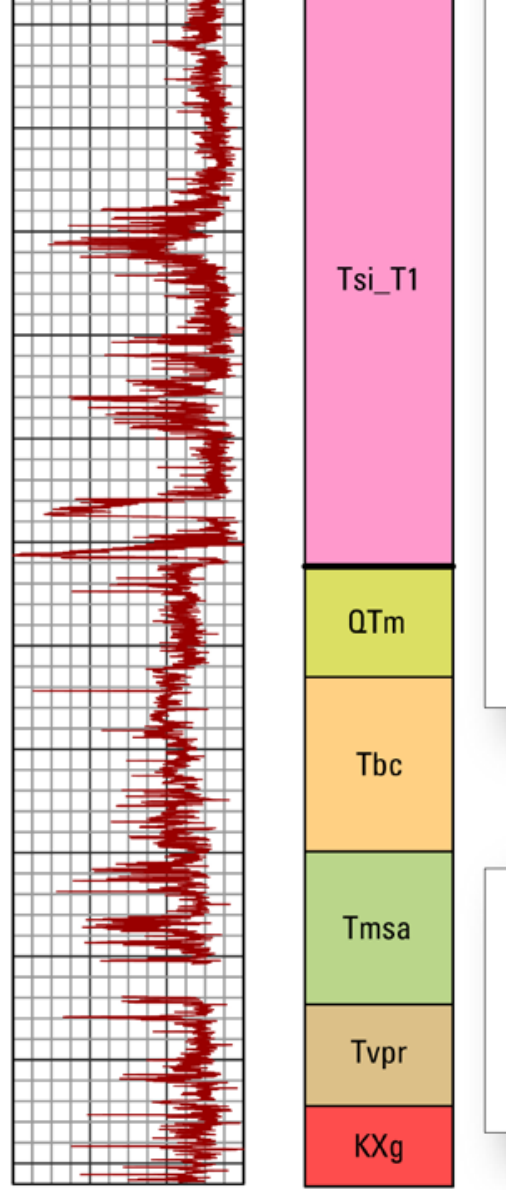

QTm: Morales Formation

Tbc: Branch Canyon Sandstone

Tmsa: Saltos Shale Member of the Monterey Formation

Tvpr: Painted Rock Sandstone

Member of the Vaqueros

Formation

$\mathrm{KXg}$ : Granite and granitic gneiss

Well: ARCO Drake Federal \#1

Well location shown on figure 7.

\section{Explanation of units shown on} stratigraphic column

Tmsa_T1: Saltos Shale Member of the Monterey Formation in

Tvpr_T1: Painted Rock Sandone Member of the Vaqueros

Tvsl_T1: Soda Lake Shale Member of the Vaqueros Formation in upper plate of thrust

si_T1: Simmler Formation in upper plate of thrust

- Thrust fault -.

KX:Granite and granitic gneiss

\section{Explanation of geophysical logs}

Off-scale values on geophysical logs are truncated at the edge of the log.

$\mathrm{ft} / \mathrm{sec}$ : feet per second

$\mathrm{g} / \mathrm{cm}^{3}$ : grams per cubic centimeter

Figure 9. Sonic and density logs from wells in Cuyama Valley and surrounding areas. A, ARCO Drake Federal \#1, API 07920417. 
$\boldsymbol{B}$

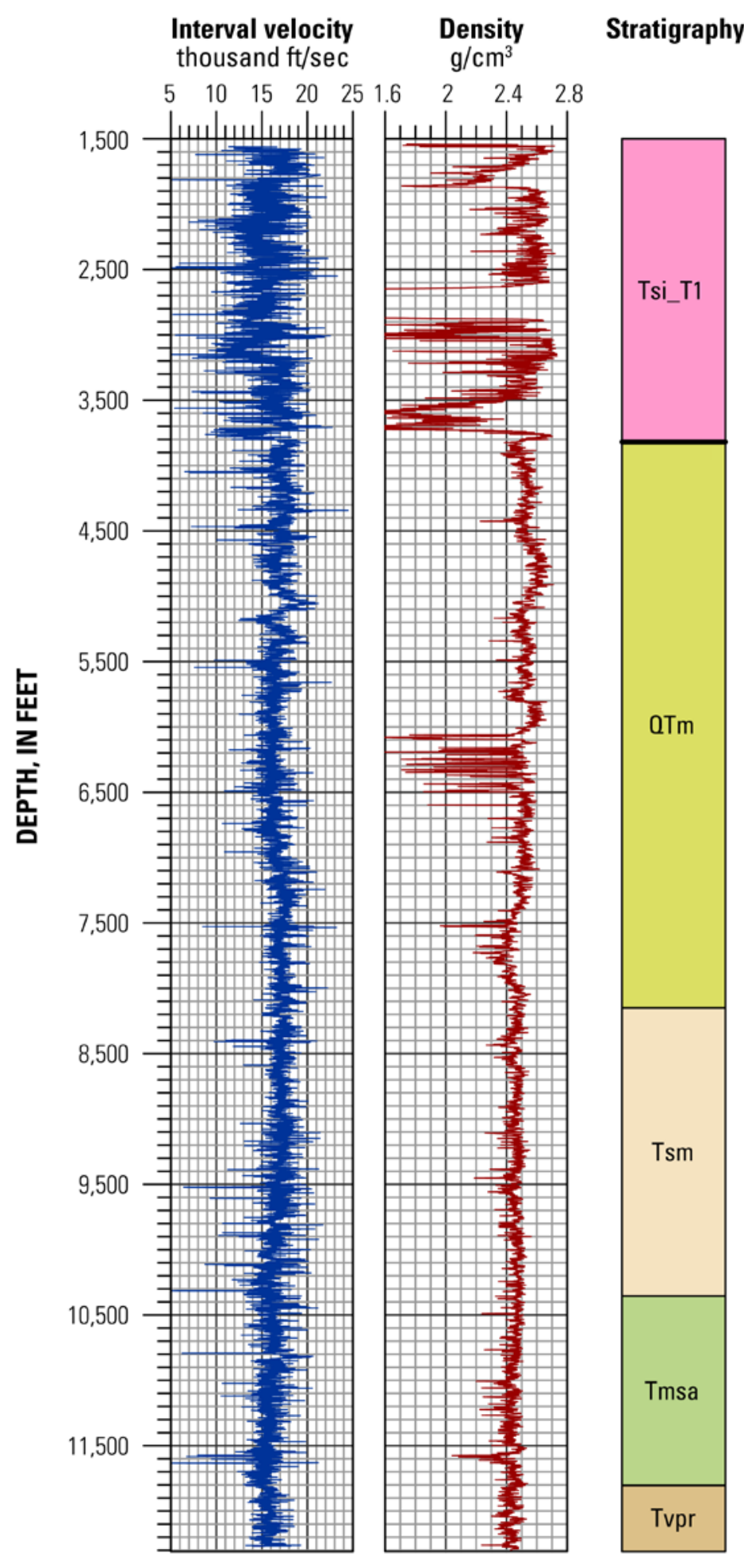

Well: Hunt Oil Federal 1-7

API: 07920769

Well location shown on figure 7.

\section{Explanation of units shown on stratigraphic column}

Tsi_T1: Simmler Formation in upper plate of thrust

-- Thrust fault --

QTm: Morales Formation

Tsm: Santa Margarita

Formation

Tmsa: Saltos Shale Member of the Monterey Formation

Tvpr: Painted Rock Sandstone Member of the Vaqueros Formation

\section{Explanation of geophysical logs}

Off-scale values on geophysical logs are truncated at the edge of the log.

$\mathrm{ft} / \mathrm{sec}$ : feet per second

$\mathrm{g} / \mathrm{cm}^{3}$ : grams per cubic centimeter

Figure 9-Continued. Sonic and density logs from wells in Cuyama Valley and surrounding areas. B, Hunt Oil Federal 1-7, API 07920769. 
C

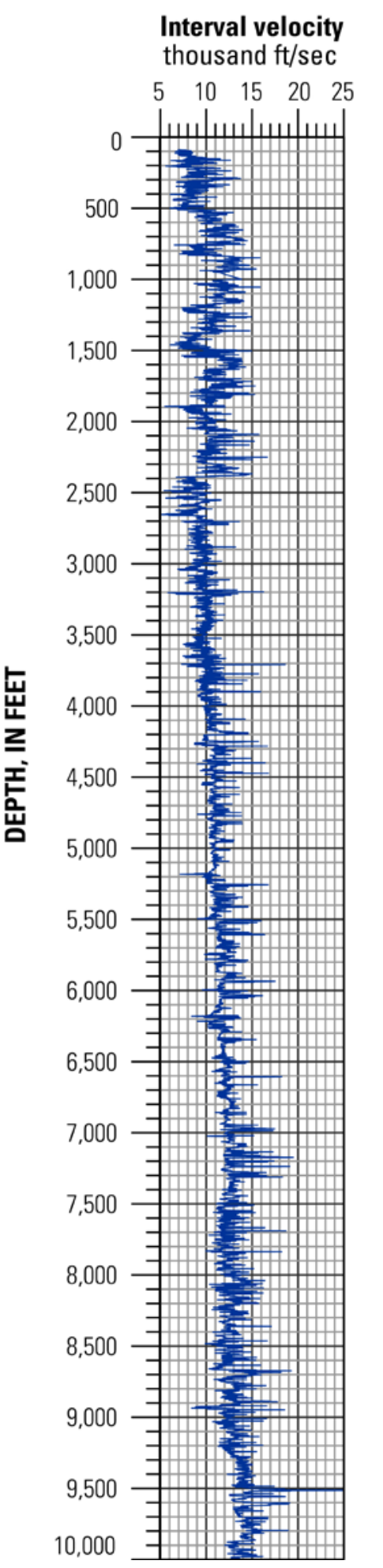

Stratigraphy

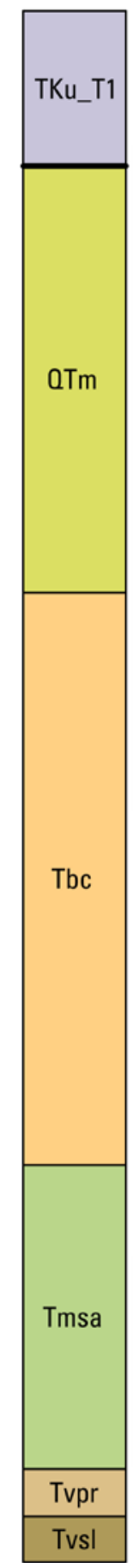

Well: Oryx J\&D Moore 1

API: 08322102

Well location shown on figure 7.

\section{Explanation of units shown on stratigraphic column}

TKu_T1: pre-Oligocene marine sedimentary rocks, undivided in upper plate of thrust

-- Thrust fault --

QTm: Morales Formation

Tbc: Branch Canyon Sandstone

Tmsa: Saltos Shale Member of the Monterey

Formation

Tvpr: Painted Rock Sandstone Member of the Vaqueros Formation

Tvsl: Soda Lake Shale Member of the Vaqueros

Formation

\section{Explanation of geophysical logs}

Off-scale values on geophysical logs are truncated at the edge of the log.

$\mathrm{ft} / \mathrm{sec}$ : feet per second

Figure 9-Continued. Sonic and density logs from wells in Cuyama Valley and surrounding areas. C, Oryx J\&D Moore 1, API 08322102. 
D

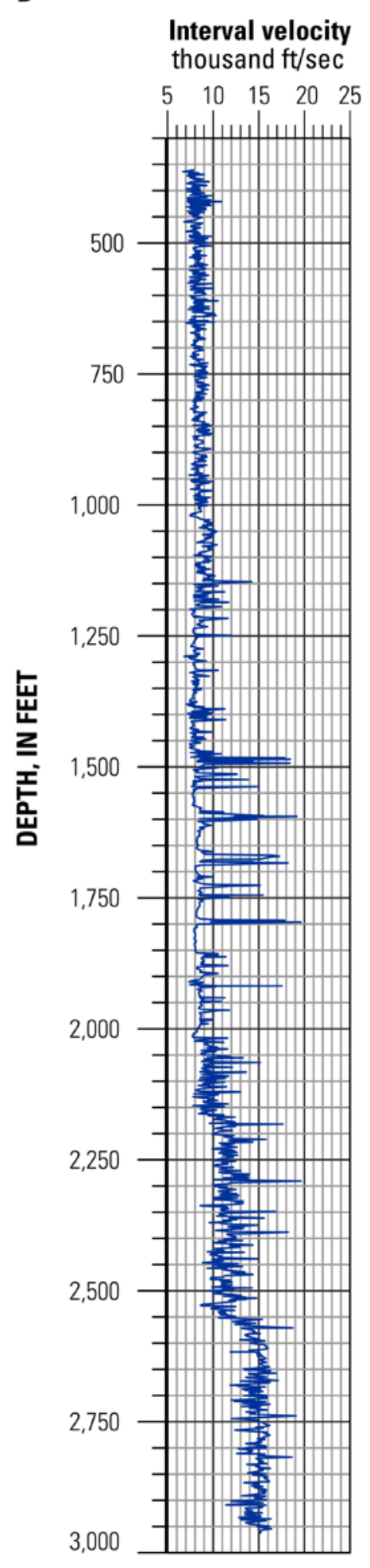

Well: J Operating Co. Mitchell 1

API: 08322161

Well location shown on figure 7 .

\section{Explanation of units shown on stratigraphic column}

Tsm: Santa Margarita

Formation

Tmwr: Whiterock Bluff Shale Member of the Monterey Formation

Tmsa: Saltos Shale Member of the Monterey Formation

TKu: pre-Oligocene marine sedimentary rocks, undivided
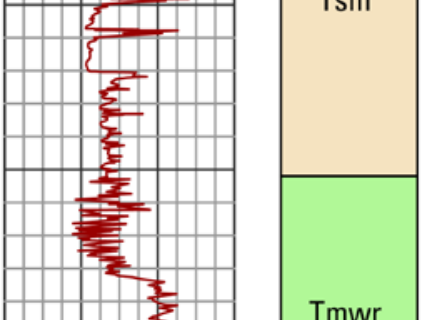

\section{Explanation of geophysical logs}

Off-scale values on geophysical logs are truncated at the edge of the log.

$\mathrm{ft} / \mathrm{sec}$ : feet per second

$\mathrm{g} / \mathrm{cm}^{3}$ : grams per cubic centimeter

Density was not logged above 730 feet.

Figure 9-Continued. Sonic and density logs from wells in Cuyama Valley and surrounding areas. D, J Operating Co. Mitchell 1, API 08322161. 
Well: J Operating Co. Los Amigos $1 \mathrm{~A}$

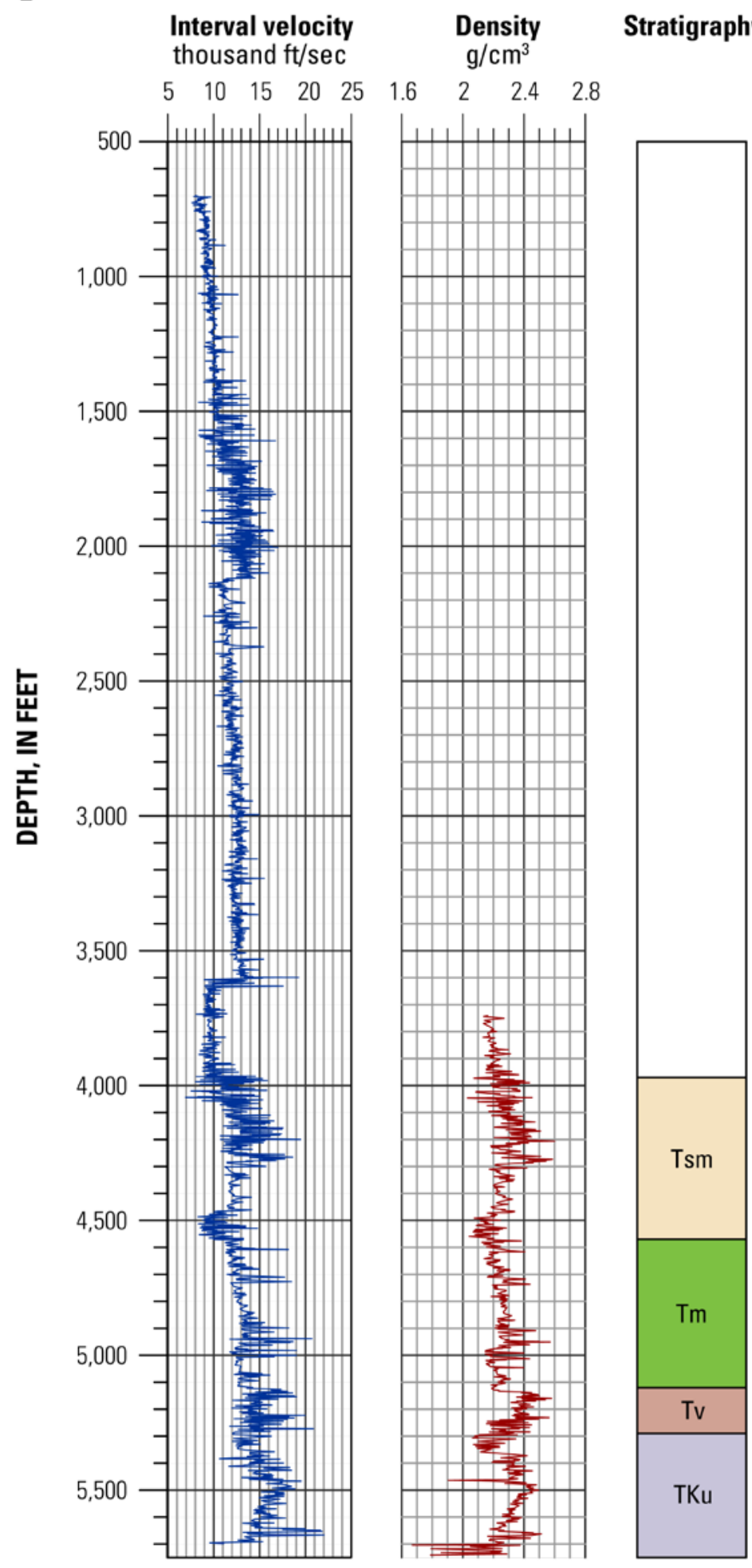

\section{Explanation of units shown on stratigraphic column}

Tsm: Santa Margarita Formation

Tm: Monterey Formation, undivided

Tv: Vaqueros Formation, undivided

TKu: pre-Oligocene marine sedimentary rocks, undivided

\section{Explanation of geophysical logs}

Off-scale values on geophysical logs are truncated at the edge of the log.

$\mathrm{ft} / \mathrm{sec}$ : feet per second

$\mathrm{g} / \mathrm{cm}^{3}$ : grams per cubic centimeter

Density was not logged above 3,750 feet.

Figure 9-Continued. Sonic and density logs from wells in Cuyama Valley and surrounding areas. $E$, J Operating Co. Los Amigos 1A, API 08322170. 


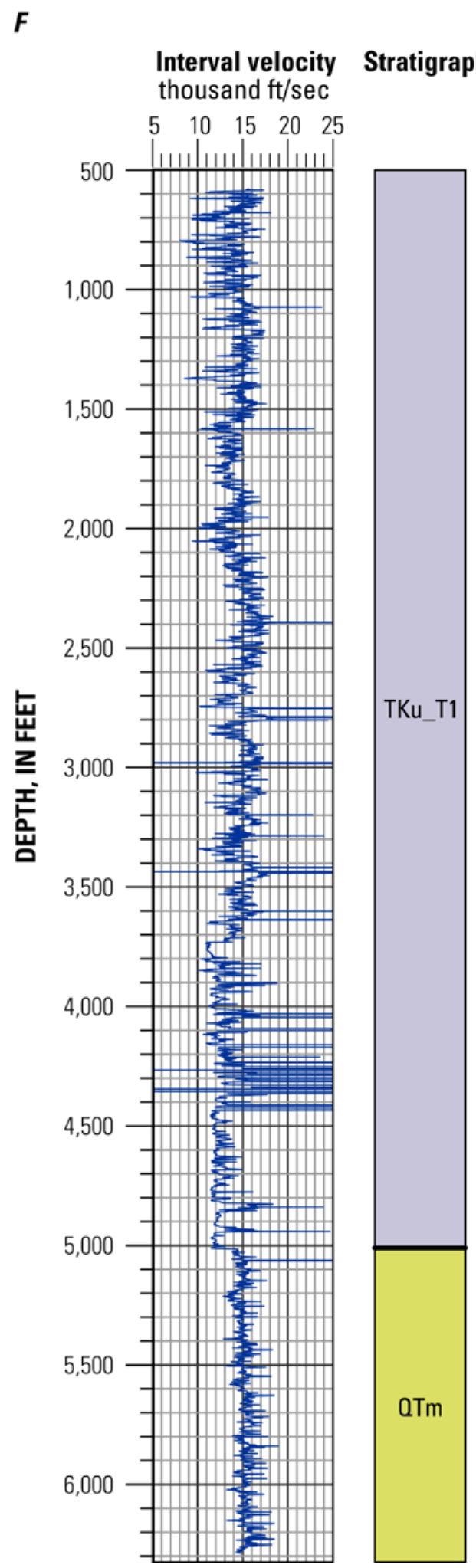

Well: Exxon Soco Federal 1

API: 08322198

Well location shown on figure 7.

\section{Explanation of units shown on stratigraphic column}

TKu_T1: pre-Oligocene marine sedimentary rocks, undivided, in upper plate of thrust

-- Thrust fault --

QTm: Morales Formation

\section{Explanation of geophysical logs}

Off-scale values on geophysical logs are truncated at the edge of the log.

$\mathrm{ft} / \mathrm{sec}$ : feet per second

Figure 9-Continued. Sonic and density logs from wells in Cuyama Valley and surrounding areas. F, Exxon Soco Federal 1, API 08322198. 


\section{Stratigraphic Assignments}

The stratigraphic units that were reported or interpreted to be intercepted downhole are tabulated in sequential fashion in appendix 1. Stratigraphic assignments relied on published discussions of regional stratigraphic variations (Hill and others, 1958; Dibblee, 1973; 1995; Bartow, 1978; 1990; Lagoe, 1984; 1987; Bazeley, 1988) and stratigraphic unit descriptions from geologic maps of the Cuyama Basin (Vedder and Repenning, 1975; Graham and others, 1999; Kellogg and others, 2008). Stratigraphic assignments were chosen to be consistent with the USGS geologic names lexicon "Geolex" (Accessed February 2013, at http://ngmdb.usgs.gov/Geolex/). The stratigraphic unit abbreviations used in appendix 1 are designed to provide easy recognition of member-level stratigraphic subdivisions but do not correspond to map unit abbreviations on any specific published geologic map of the Cuyama Valley area. In some cases, stratigraphic units were described in the original data sources using local stratigraphic names or names used in other southern California oil fields. In these cases, we have reinterpreted the reported units and assigned them to stratigraphic units that have regional significance for the Cuyama Basin.

Stratigraphic tops for each well were compiled by first transcribing reported formation top data from all available sources. Electric logs for each well were examined and interpreted and the previously reported formation picks were adjusted as needed. Typically, several nearby wells were interpreted together to maintain a consistent interpretation.

The alternating sand-shale sequences in the Monterey and Vaqueros Formations in the subsurface of Cuyama Valley result in electric-log signals that are readily identified. Both the Saltos Shale Member of the Monterey Formation and the Soda Lake Shale Member of the Vaqueros Formation are identified on electric logs by inward deflections of the SP-curve (rightward, towards more positive values) and the resistivity curves (leftward, towards smaller resistivity values) (Keys and MacCary, 1971; Johnson and Pile, 2002), particularly on the SP $\log$ (figs. $8 A$ and $8 B$ ). Beneath the eastern half of the valley, the thick-bedded-to-massive Branch Canyon Sandstone is identified by large outward deflections of the SP-curve (leftwards, towards more negative values) and the resistivity curves (rightward, towards larger resistivity values) (fig. $8 B$ ). The appearance of thrust faults on the electric logs depends upon the electrical properties of the rock units that are juxtaposed by the thrust. In some cases, the fault may appear as an abrupt transition on electric logs; elsewhere, the transition may be subtle (fig. 8B). The position of the thrust fault can often be corroborated with a cuttings log or mud log. Wells in the Cuyama Badlands penetrate the continental section; these wells typically have a very irregular electric log character (fig. 8C).

\section{Explanation of Column Headings and Abbreviations in Data Table Appendix}

The data tabulated in appendix 1 include well location and stratigraphic information for oil and gas exploration wells from the Cuyama Basin (fig. 2). Below we describe the column headings and content of each data field within the appendix. Well records are given two primary identifiers: ID, a unique well identifier assigned by us, and, where available, the API well number (APINUMBER), described below.

ID: ID is a unique well identifier assigned by us. This number is useful in the two cases where a well has no API well number.

APINUMBER: The API well number (APINUMBER) is a unique, permanent, numeric identifier assigned to nearly every well drilled for oil and gas in the United States. The numbers reported here are abbreviated versions of the full API well number and consist of a three-digit county code followed in sequence by a five-digit unique well identification number within the county. County codes 
are as follows: 029, Kern County; 079, San Luis Obispo County; 083, Santa Barbara County; and 111, Ventura County.

OPERATOR, LEASE, WELL_NO: Well operator (OPERATOR), lease name (LEASE), and well number (WELL_NO) within the lease. These attributes were obtained in a digital well location database from the CA DOGGR (Accessed February 2013, at http://www.conservation.ca.gov/dog/maps/Pages/GISMapping2.aspx/). We have modified some name abbreviations for clarity and consistency, but for the most part, we have retained names, abbreviations, and punctuation, as reported by the CA DOGGR. Operator names as reported in the CA DOGGR digital well location database occasionally differed from those reported in the yearly prospect well records, indicating that the operator changed since completion of the well. In most cases, the lease name and well number remain the same.

COUNTY: The county within which the well was drilled.

FIELD: The name of the producing oil and gas field within which the well is located, as reported by the CA DOGGR. For wells located outside of recognized producing fields, the CA DOGGR assigns the name of the county as the field name.

$T W N, R G E, S E C, B M$ : Denotes location of the well according to its location in the rectangular system for the subdivision of public lands by the United States Public Land Survey. Identification consists of the township number (TWN), north or south; the range number (RGE), east or west; and the section number (SEC). In California, township and range designations are referenced to one of three principal base line and meridians (BM) which serve as the reference point for measuring north or south townships and east or west ranges. All wells in the study area are referenced to either the Mount Diablo (MD) or San Bernardino (SB) base line and meridians. The dividing line separating the region referenced to the San Bernardino base line and meridian and the area referenced to the Mount Diablo base line and meridian roughly follows the Santa Barbara County-San Luis Obispo County boundary in the northern part of the study area.

LATITUDE, LONGITUDE: Well locations in decimal degrees, as reported in a digital well location database obtained from the CA DOGGR (Accessed February 2013, at http://www.conservation.ca.gov/dog/maps/Pages/GISMapping2.aspx/). Horizontal coordinate information is referenced to the North American Datum of 1983 (NAD 83), GRS 80 spheroid. A small number of wells were obtained from student theses that are not present in the CA DOGGR well database. These wells were assigned horizontal coordinates by geographically referencing a well location map from the thesis within a GIS and digitizing the well location.

NORTHING, EASTING: Well locations, in meters, in Albers projected coordinate system, North American Datum of 1983 (NAD 83), GRS 80 spheroid. The Albers coordinate system was chosen because Cuyama Valley lies in two zones of the Universal Transverse Mercator (UTM) system, making use of the UTM system problematic.

$\boldsymbol{L S} \boldsymbol{A} \_\boldsymbol{f t}$ : Land surface altitude (LSA) at the well location, in feet, relative to mean sea level. Values are reported in feet to maintain consistency with source geologic and geophysical data for which depths are reported in feet. Values were initially tabulated from the CA DOGGR prospect well reports, well-closure reports, or from the header information shown on electric logs. The reported altitudes were then compared to a digital elevation model (DEM) for accuracy, since the entries in the prospect well records and well-closure reports cannot be readily verified, and many of these data may have been estimated from a topographic map. Elevation differences with a DEM could also indicate that the well was mislocated, although this could not be verified. Land surface altitudes obtained from a DEM with 10-m resolution were compared to the reported altitudes; reported values were replaced by the DEM value where the reported value differed from the DEM altitude by 10 meters or more. Wells for which no land surface altitude was reported were assigned an altitude based on the DEM. 
MP: The measuring point (MP) is the arbitrary datum point from which depths in the well were measured. This point may be reported as land surface (LS), or some reference point on the drilling rig including the drilling rig floor (DF), the Kelly Bushing (KB), or the rotary table (RT). For wells where the measuring point was not specified, the measuring point is assumed in this report to be land surface.

MP_height_ft: The height of the measuring point, in feet, above land surface altitude at the well location.

MP_Elev_ft: The elevation of the measuring point, in feet, relative to mean sea level. Obtained by adding the height of the measuring point to LSA at the well location, rounded to the nearest foot.

TD_ft: Total drilled depth, in feet. Values are reported in feet to maintain consistency with source geologic and geophysical data for which depths are reported in feet. Values were tabulated from the CA DOGGR digital well location database, prospect well reports, well-closure reports, or from the header information shown on electric logs.

Data_Source: The primary source or sources from which well stratigraphic data were derived. Most of the wells had electric logs available; for these wells, stratigraphic tops from other sources were verified or adjusted based on interpretation of the electric logs.

Fault: Faults intersected at depth by a well are listed by name, if known, followed by the depth, in feet, to the fault. Minor faults that do not repeat or omit section or that cause only minor changes to stratigraphic thickness are ignored.

\section{Tabulation of depths to top of stratigraphic unit}

The stratigraphic units that were reported or interpreted to be intercepted downhole are tabulated in sequential fashion in appendix 1 and described below. Appendix 1 lists drilled depth to the top of each stratigraphic unit in feet. Values are reported in feet to maintain consistency with source geologic and geophysical data for which depths are reported in feet. Formation tops with a depth of zero are exposed at land surface and indicate that the well spudded in the listed formation; these tops were obtained by intersecting each well location with a digital geologic map (fig. 2) within a GIS. Formation tops preceded by a "less than" symbol $(<)$, inserted as a separate column labeled "LT," denote cases where the top of the formation is above the start of the electric log, so that the top of the log only provides a limiting value for the elevation of the stratigraphic unit. All formation tops are reported in appendix 1 as measured depth, the depth as measured along the length of the borehole. Some recent wells in Cuyama Valley have been drilled as directional, nonvertical boreholes. For these wells, the reported measured depth to a formation top is greater than the true vertical depth (TVD), which is the vertical distance from the formation top to the elevation of the measuring point at the surface. TVD may be calculated from the measured depth using the results from a directional survey of the borehole, typically available from CA DOGGR.

Bedrock stratigraphic units that are repeated by thrust faults are tabulated in separate columns from the nonthrusted, or autochthonous, units. Where a single thrust fault is present, bedrock units in the hanging wall above the thrust fault are tabulated in columns in which the identifier "_T1" is appended to the unit abbreviation. Where two thrust faults are present, bedrock units in the thrust plate that immediately overlie the nonthrusted, or autochthonous, units are tabulated in columns in which the identifier "_T1" is appended to the unit abbreviation; units in the structurally higher thrust plate are tabulated in columns in which the identifier "_T2" is appended to the unit abbreviation. Only those wells that could be shown to be underlain at depth by a thrust fault are tabulated in the _T1 and _T2 columns; stratigraphic units from wells in the Caliente and Sierra Madre Ranges that neither penetrate a thrust fault nor intersect underlying younger section are arbitrarily tabulated as nonthrusted units 
(fig. 8). Not every stratigraphic unit tabulated in the nonthrusted section has a counterpart in the _T1 and _T2 columns; only those stratigraphic units identified in thrust sheets are listed. Wells were interpreted to intersect faulted sections where older rocks were reported to overlie younger rocks or where fault zones were reported downhole (fig. 10). We made no attempt to identify structural omission or thinning of units by normal faults. 


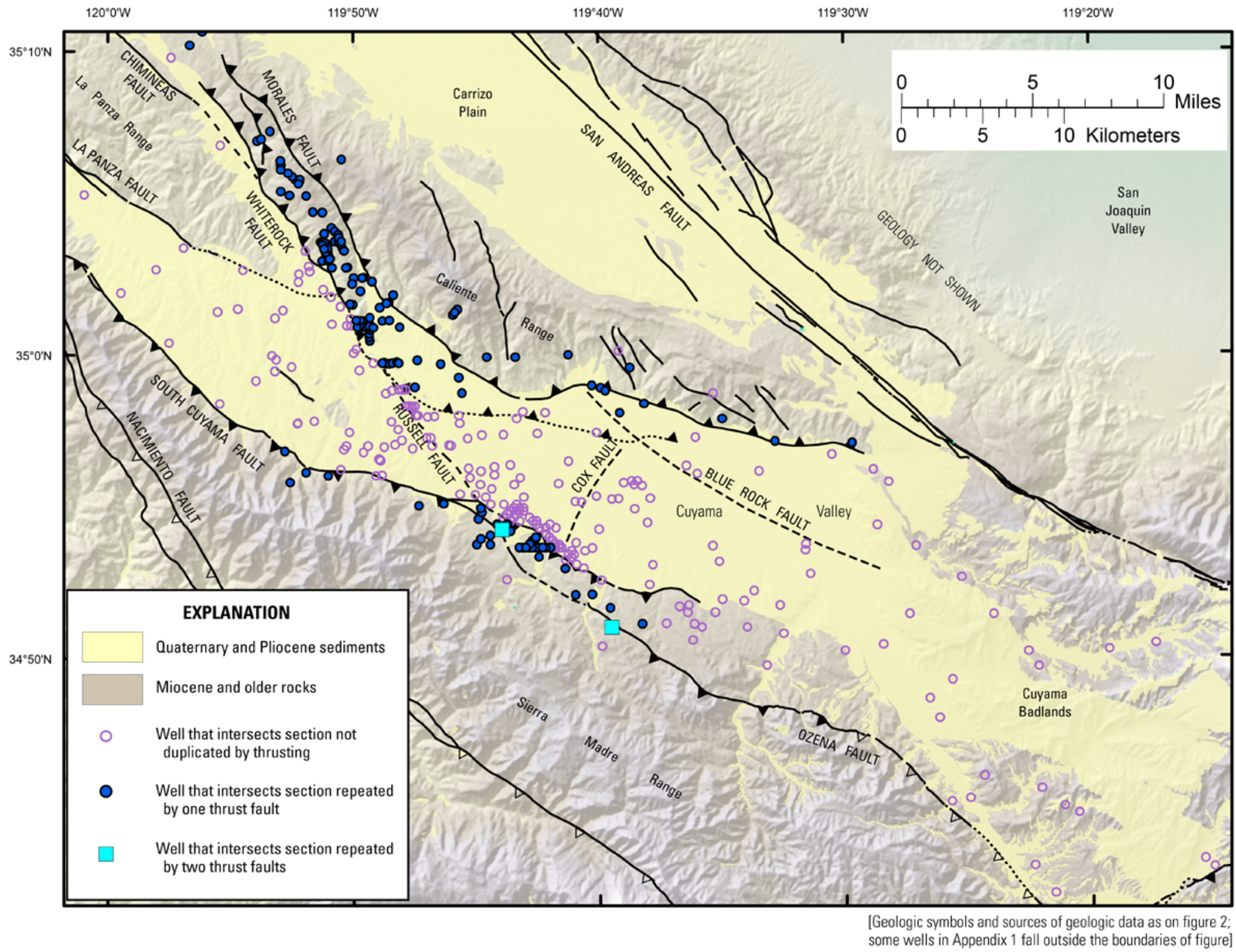

Figure 10. Map showing the location of wells in Cuyama Valley where the stratigraphic section is not duplicated by thrusting, and the location of wells in surrounding range blocks where the section is repeated by one or two thrust faults. 
QTm: Morales Formation: The nonmarine Morales Formation primarily is a fluvial deposit at least 1,400 m thick consisting of massive- to thick-bedded, partly consolidated deposits of gravelly arkosic sand with local gravel beds and siltstone (Hill and others, 1958; Ellis and others, 1993). The formation is predominantly Pliocene in age; Kellogg and others (2008) present data that suggest that the formation may be in part Pleistocene in age. The Morales Formation unconformably overlies middle and upper Miocene strata and generally postdates offset on the Russell fault (Yeats and others, 1989). In the subsurface, this formation is characterized by a generally subdued electric-log response consisting of numerous small-amplitude peaks on both SP and resistivity logs, with no major sandy or fine-grained intervals present (fig. 8B). In general, the Morales Formation is difficult to subdivide from overlying alluvial materials. The top of the Morales Formation is only tabulated where it is overlain by thrusted bedrock units. In nonthrusted areas, the top of the Morales Formation is not tabulated, and formation tops begin with units beneath the Morales Formation.

Tq: Quatal Formation. The Pliocene Quatal Formation is a nonmarine claystone and sandstone sequence that underlies the Morales Formation (Hill and others, 1958; Vedder, 1968; Kellogg and others, 2008). In the Cuyama Badlands, it consists of $250 \mathrm{~m}$ of reddish-gray, gypsiferous claystone, but thickens southward to $825 \mathrm{~m}$ of pebbly sandstone, thin gypsum beds, and a basal mudstone (Vedder, 1968; Kellogg and others, 2008).

In the subsurface beneath the eastern half of Cuyama Valley, the Quatal Formation is identifiable as a fine-grained unit that underlies the Morales Formation and appears on electric logs as distinctive inward deflections of both the SP and resistivity curves (fig. 8B). This fine-grained interval is up to $100 \mathrm{~m}$ thick in the southeast part of Cuyama Valley; the unit thins to the northwest to a persistent 10- to 15-m-thick layer, eventually pinching out in the vicinity of the Russell fault (Ellis and Spitz, 1987; Ellis, 1994) (fig. 4).

Tsm: Santa Margarita Formation. The middle and upper Miocene Santa Margarita Formation is well exposed in the Caliente Range, where it overlies the Monterey Formation (Graham and others, 1999), and the Sierra Madre Range where it overlies the Branch Canyon Sandstone (Vedder and Repenning, 1975; Kellogg and others, 2008). In outcrop exposures, the formation consists of up to $300 \mathrm{~m}$ of alternating sandstone and mudstone units. The sandstone intervals consist of fine- to coarsegrained and pebbly, thick-bedded to massive fossiliferous white sandstone; the fine-grained intervals consist of mudstone, siliceous mudstone, and phosphatic mudstone with interbedded pelletal phosphatic sandstone (Hill and others, 1958; Lagoe, 1987). The formation is often separated from the underlying Branch Canyon Sandstone by a persistent, phosphatic claystone (Hill and others, 1958). The Santa Margarita Formation is a minor producer of oil in both the Russell Ranch and South Cuyama oil fields (Barger and Zulberti, 1952; Zulberti, 1954; Hill and others, 1958).

In the western part of Cuyama Valley, the electric log character of the Santa Margarita Formation is typically distinctive enough that the formation can be confidently separated from the underlying Branch Canyon Sandstone. The Santa Margarita Formation typically has smaller amplitude deflections and higher bedding frequency compared to the thicker bedded, higher amplitude, "blocky" response of the underlying Branch Canyon Sandstone (Schwing, 1984).

Tbs: Santa Margarita Formation and Branch Canyon Sandstone, undivided. This unit designation has been used in the subsurface in the South Cuyama oil field (Schwing, 1984) and beneath the southeastern part of Cuyama Valley (Lagoe, 1984; Spitz, 1986) for intervals that cannot be definitively correlated with either formation (fig. 4). In these areas, up to $130 \mathrm{~m}$ of marine sandstone and interbedded siltstone conformably overlie the Branch Canyon Sandstone. However, the lack of paleontological age control and the absence of distinctive, correlatable lithologies prevent the definitive correlation of this interval with either the Branch Canyon Sandstone or the Santa Margarita Formation 
(Schwing, 1984; Spitz, 1986). The presence of numerous fine-grained interbeds results in a "jagged" electric-log response that contrasts with the "blocky" electric-log character, particularly the SP log, of the underlying massively bedded Branch Canyon Sandstone (figs. $8 A$ and $8 B$ ). A thick sequence of marine sandstone and interbedded siltstone penetrated by wells on the southwest side of the Russell fault and in the footwall of the South Cuyama thrust fault is included as part of unit Tbs (Schwing, 1984). This thick section is neither readily correlated to strata to the northeast of the Russell fault nor to strata in the upper plate of the South Cuyama thrust.

Tbc: Branch Canyon Sandstone. The Branch Canyon Sandstone is a lower and middle Miocene thick-bedded to massive marine sandstone (Hill and others, 1958; Dibblee, 1973). The Branch Canyon Sandstone is exposed in the Caliente Range and the Sierra Madre Mountains (fig. 2), where it ranges in thickness from 750 to 1,000 m (Hill and others, 1958; Graham and others, 1999). Beneath Cuyama Valley, the unit overlies and intertongues with the deep-marine Monterey Formation to the west and southwest and with continental rocks of the Caliente Formation to the east and northeast (fig. 4) and is interpreted as a shallow-marine strandline deposit separating deeper marine and continental rocks (Hill and others, 1958; Clifton, 1981; Lagoe, 1984; 1987).

The unit is present in the subsurface beneath much of Cuyama Valley, where it appears as a 125to 200-m thick interval overlying the Saltos Shale Member of the Monterey Formation (Hill and others, 1958; Schwing, 1984). The unit is recognized by its stratigraphic position and massive bedding that results in a "blocky" electric-log response (for example, the interval between 2,825 ft and 3,150 ft) (fig. 8A). SP and resistivity logs often show "funnel-shaped" patterns indicative of coarsening upwards sequences (Lagoe, 1987) (for example, the interval between 3,050 ft and 3,100 ft) (fig. 8A). Underlying the main body of Branch Canyon Sandstone in the South Cuyama field are a series of thick, tabular sands that have a similar electric-log response but are interbedded with the upper part of the Saltos Shale Member of the Monterey Formation (Schwing, 1984). Zulberti (1954) called these the Johnston sands, an informal designation also used in subsequent subsurface work by Schwing (1984) and Spitz (1986). Zulberti (1954) included the Johnston sands in the upper part of the Monterey Formation, whereas Schwing (1984) and Spitz (1986) designated the Johnston sands as a lower, informal member of the Branch Canyon Sandstone on the basis of their probable early to middle Miocene age, massive nature and similar electric-log response. This designation is used here, although portions of the Johnston sands interval might better correlate to the Hurricane Deck Formation defined in the Sierra Madre Mountains (Perri and Fritsche, 1988; Thomas and others, 1988). The Branch Canyon Sandstone is occasionally referred to informally in well reports as "Bitter Creek sands" (Zulberti, 1954).

Tm: Monterey Formation, undivided. The lower to middle Miocene Monterey Formation is a widespread, siliceous organic shale that overlies the Vaqueros Formation and grades laterally eastward into the shallow water marine Branch Canyon Sandstone which in turn grades eastward into nonmarine Caliente Formation (Hill and others, 1958; Vedder, 1973; Lagoe, 1984; 1987). The Monterey Formation in the Cuyama Basin is typically mapped as having two members: an upper Whiterock Bluff Shale Member and a lower Saltos Shale Member (Hill and others, 1958; Graham and others, 1999) (figs. 3 and 4). The undivided designation, $\mathrm{Tm}$, is only used in about 40 boreholes where the original source data did not subdivide the Monterey Formation at the member level, and no additional data, such as electric logs, were available to interpret such divisions.

Tmwr: Whiterock Bluff Shale Member of the Monterey Formation. The mostly middle Miocene Whiterock Bluff Shale Member consists of deep water marine calcareous mudstone and shale in its lower part, and diatomaceous shale, siliceous shale, and diatomite in its upper part (Lagoe, 1984; 1987). It occurs in the Caliente Range in the upper plates of Whiterock and Morales thrust faults and in surface exposures above the Russell Ranch field (Hill and others, 1958; Calhoun, 1986; Graham and 
others, 1999). The Whiterock Bluff Member conformably overlies the Saltos Shale Member; the contact in surface exposures is gradational and is mapped as an upward transition from calcareous shale to siliceous and diatomaceous shale and generally corresponds with a color change from dark brown below to bleached white above (Hill and others, 1958).

In the subsurface, the Whiterock Bluff Member is not recognized in the South Cuyama field or in the southeastern part of Cuyama Valley; in those locations, the interval is occupied by the Branch Canyon Sandstone (Lagoe, 1984; 1987; Schwing, 1984; Spitz, 1986) (fig. 4). Nevins (1982) tentatively identified a 120-m-thick section of Whiterock Bluff Member in the Russell Ranch field in the lower plate of the Whiterock thrust that appeared to grade laterally into Branch Canyon Sandstone. Both Nevins (1982) and Calhoun (1986) recognize the Whiterock Bluff Member in the upper plate of the Whiterock thrust where the unit is up to $500 \mathrm{~m}$ thick. The unit is distinguished in the subsurface from the underlying Saltos Shale Member by a more pronounced jagged electric-log character, particularly on the SP $\log$.

Tmsa: Saltos Shale Member of the Monterey Formation. The lower Miocene (Saucesian to Relizian) Saltos Shale Member conformably overlies the Vaqueros Formation and grades upward into the Whiterock Bluff Member (Hill and others, 1958; Lagoe, 1984; 1987). The Saltos Shale Member is interpreted as abyssal basin-plain deposits that represent the second major deep-water transgression of the Cuyama Basin (Lagoe, 1984; 1987; Fritsche, 1988). In outcrop in the Caliente Range, the Saltos Shale Member consists of up to $650 \mathrm{~m}$ of argillaceous and siliceous mudstone and shale with subordinate muddy carbonates (Hill and others, 1958; Lagoe, 1984; 1987). Vedder and Repenning (1975) mapped an informal lower unit of the Monterey Formation in the upper plate of the South Cuyama thrust which may correlate with the subsurface Saltos Shale Member.

The Saltos Shale Member is widespread in the subsurface throughout the Cuyama Basin. In the subsurface, the unit varies from less than $30 \mathrm{~m}$ thick in the South Cuyama field (Zulberti, 1954; Schwing, 1984) to as much as 1,375 m thick on the down-thrown east side of the syndepositional Cox fault (Lagoe, 1984; Schwing, 1984; Spitz, 1986) (fig. 2). The unit is about $300 \mathrm{~m}$ thick in the Russell Ranch field (Barger and Zulberti, 1952; Nevins, 1982); west of the Russell fault the unit is considerably thinner, ranging in thickness from $45 \mathrm{~m}$ to approximately $180 \mathrm{~m}$ (Nevins, 1982; Calhoun, 1986). In the eastern part of Cuyama Valley, to the east of the South Cuyama field, the Saltos Shale Member is the only member of the Monterey Formation present and contains significant amounts of interbedded sandstone, which represent submarine fan complexes that interfinger westward with basin-plain facies (Lagoe, 1984; 1987). These lithofacies complicate the electric-log response of the Saltos Shale Member, often creating resistive peaks or serrate SP and resistivity log responses in what would otherwise be a very subdued response from a shale-dominated section (Lagoe, 1984; 1987; Schwing, 1984; Spitz, 1986) (fig. 8B).

Tv: Vaqueros Formation, undivided. The Vaqueros Formation of Hill and others (1958) is a sequence of Oligocene to Miocene marine sandstone, siltstone, and shale that conformably underlies the Monterey Formation. Throughout most of the Cuyama Basin, the formation is divided into three members; in ascending order, these are the Quail Canyon Sandstone, Soda Lake Shale, and Painted Rock Sandstone Members (Hill and others, 1958; Dibblee, 1973) (figs. 3 and 4). Locally in the La Panza Range, the Sierra Madre Mountains, and the Cuyama Badlands, the Vaqueros is a thin, undivided unit of mostly sandstone (Bartow, 1978; Kellogg and others, 2008) (fig. 2). The identifier Tv is used in appendix 1 for 16 boreholes from the above-mentioned areas where the original source data did not subdivide the Vaqueros Formation at the member level and regional considerations suggest that member subdivision is unwarranted. 
Tvpr: Painted Rock Sandstone Member of the Vaqueros Formation. The lower Miocene Painted Rock Sandstone is the uppermost member of the Vaqueros Formation and in surface exposures consists of as much as 1,650 m of thick-bedded, medium-grained arkosic sandstone with common interbeds of siltstone and silty sandstone (Hill and others; 1958; Dibblee, 1973; Bartow, 1990). These coarse-grained deposits represent a variety of shallow-marine and deltaic environments that marked the end of the lower Miocene marine transgression (Lagoe, 1987; Fritsche, 1988; Bartow, 1990). The Painted Rock Sandstone Member is the main producing horizon in the South Cuyama and Russell Ranch oil fields, where it is referred to informally as the "Dibblee sand" or the "Dibblee zone" in well reports (Zulberti, 1954; Nevins, 1982; Schwing, 1984). The Painted Rock Sandstone Member is occasionally referred to informally in well reports as "Temblor sands" (Eaton and others, 1941).

In the subsurface, the unit is 100 to $250 \mathrm{~m}$ thick and is subdivided into several subunits where productive sands are separated by intervening shale units (Zulberti, 1954). The unit is recognized on electric logs by its overall outward deflection on both SP and resistivity logs compared to the overlying Saltos Shale Member of the Monterey Formation and the underlying Soda Lake Shale Member of the Vaqueros Formation. However, complex facies patterns within the Painted Rock Sandstone Member (Bartow, 1990) make the electric-log response of this unit complex and variable in detail (figs. $8 A$ and $8 B$ ).

Tvsl: Soda Lake Shale Member of the Vaqueros Formation. The Soda Lake Shale Member consists of 300 to $600 \mathrm{~m}$ of dark gray siltstone and shale with thin sandstone interbeds (Hill and others, 1958; Dibblee, 1973; Bartow, 1990; 1995). This unit is interpreted as a deep basinal-marine deposit, mostly represented by turbidites deposited in a rapidly subsiding basin (Bartow, 1990).

In the subsurface, the Soda Lake Shale Member is identified on electric logs by generally consistent inward deflection on both SP and resistivity logs, with relatively few thin sands within the interval (figs. $8 A$ and $8 B$ ). Well reports commonly refer informally to this unit as "Colgrove shale."

Tvqc: Quail Canyon Sandstone Member of the Vaqueros Formation. The Quail Canyon Sandstone Member is the basal member of the Vaqueros Formation and consists of up to $100 \mathrm{~m}$ of fineto medium-grained, massively bedded sandstone (Hill and others; 1958; Dibblee, 1973). This Oligocene unit is a basal transgressive shallow-marine deposit (Bartow, 1978; 1990) that overlies the Simmler Formation or the older, pre-Oligocene marine section (fig. 3). Surface exposure of this member is limited to the Caliente Range (Hill and others; 1958; Graham and others, 1999) (fig. 2), but it is widely present in the subsurface (Nevins, 1982; Schwing, 1984; Calhoun, 1986; Spitz, 1986). This sandstone is a productive oil reservoir in the Taylor Canyon and Morales Canyon oil fields (Calhoun, 1986), and in the South Cuyama field (Zulberti, 1954; Schwing, 1984).

This sand unit is identified on electric logs as 30- to 100-m-thick interval having outward deflections of the SP-curve (leftwards, towards more negative values) and the resistivity curves (rightward, towards larger resistivity values) beneath the Soda Lake Shale Member interval (fig. 8A).

Electric-log response shows relatively constant outward deflection for the thickness of the unit, with few shale interbeds. This unit typically contrasts with log response of the overlying Soda Lake Shale Member and underlying coarse clastic sediments of the Simmler Formation or the older, pre-Oligocene marine section. Well reports commonly refer to this unit informally as "Colgrove sand" or, less commonly, the "Hibberd sand" (Zulberti, 1954).

Tc: Caliente Formation. The Miocene Caliente Formation is present at the surface east of the study area in the Cuyama Badlands (fig. 2), where it consists of a sequence of poorly sorted red and green claystone, sandstone, and conglomerate 1,000 m thick (Hill and others, 1958; Dibblee, 1982; Kellogg and others, 2008). The Caliente Formation is overlain by the nonmarine Quatal and Morales Formations (fig. 4). The nonmarine strata of the Caliente Formation grade westward into the upper part of the Vaqueros Formation and into the Monterey Formation and Branch Canyon Sandstone (Vedder, 
1973; Clifton, 1981; Dibblee, 1982; Lagoe, 1984; 1987) (fig. 4); the presence of the upper part of the Caliente Formation beneath the Pliocene Quatal Formation suggests that the upper part of the Caliente Formation may also be the lateral equivalent to part of the marine middle and upper Miocene Santa Margarita Formation (Dibblee, 1973; Vedder, 1973).

The electric log character of the Caliente Formation is distinctive in having repeated abrupt transitions between rounded peaks and troughs. The upper contact of the Caliente Formation with the overlying nonmarine strata is often difficult to pick due to the lithologic similarity of the nonmarine units. Typically, the overlying Morales Formation has an electric log character that is more monotonous, with both peaks and troughs of lower amplitude than the Caliente Formation (fig. 8C).

Tsi: Simmler Formation. The Simmler Formation (Hill and others, 1958; Bartow, 1978; Blake, 1982 ) is an Oligocene nonmarine unit up to $1,000 \mathrm{~m}$ thick that consists of red to gray continental fluvial sandstone, conglomerate, and siltstone. Conglomerate predominates in exposures in the La Panza Range and in the Cuyama Gorge to the west of Cuyama Valley (fig. 1), whereas sandstone predominates in exposures in the Caliente Range (Bartow, 1978; Blake, 1982). The Simmler Formation unconformably overlies pre-Oligocene marine sedimentary rocks and is conformably overlain by the Vaqueros Formation (figs. 3 and 4). Lithologically similar rocks of uncertain affinity underlie the Vaqueros Formation in the Sierra Madre Mountains; Kellogg and others (2008) refer to these rocks informally as "Nonmarine rocks of Santa Barbara Canyon." Well reports informally refer to this interval as "Pato red beds." For the purposes of this report, we adopt the usage of Bartow (1978) and Blake (1982) by including this sequence in the Sierra Madre Mountains within the Simmler Formation on the basis of lithology and stratigraphic position (fig. 2).

In the subsurface, the Simmler Formation is identified from drill cuttings on the basis of its red color, muddy matrix, and absence of marine fossils. Sandstone and mudstones form a series of finingupward cycles that result in a characteristic "spiky" pattern on electric logs (fig. 8C). Thickness in the subsurface is variable and ranges from 0 to $350 \mathrm{~m}$. Thickness variations, especially in the conglomeratic facies, have been interpreted to be the result of alluvial-fan deposition adjacent to Oligocene normal faults (Bartow, 1978; Ballance and others, 1983).

TKu: pre-Oligocene marine sedimentary rocks, undivided. Thick sequences of pre-Oligocene marine sedimentary rocks are exposed in the La Panza Range and Sierra Madre Mountains (Graham and others, 1999; Kellogg and others, 2008) (figs. 1 and 2). The sequence ranges in age from Cretaceous to Eocene. The sequence is up to 9,000 $\mathrm{m}$ thick in the La Panza Range (Chipping, 1972; Dibblee, 1973), where it overlies Cretaceous granite (fig. 1); it is at least 6,000 m thick in the Sierra Madre Mountains with the base of the sequence not exposed (Chipping, 1970; 1972). These units are overlain with angular unconformity by the Simmler Formation or, in the absence of Simmler Formation, by the Vaqueros Formation.

Surface exposures consist of turbiditic sandstones with interbeds of indurated shale, siltstone, and some conglomerate (Hill and others, 1958; Chipping, 1970; 1972; Dibblee, 1973). Exposures of part of this sequence in the southeastern part of the Caliente Range were mapped as Paleocene-age Pattiway Formation (Hill and others, 1958), and well reports often use this name or refer to the rocks as "Cretaceous." Due to lack of age control, overall monotony of the sequence, and limited subsurface intervals penetrated, this sequence is not subdivided in this report.

$\boldsymbol{K X g}$ : Granite and granitic gneiss, undivided. Crystalline basement rock in the study area is of generally two types: (1) Cretaceous granitic rocks that are exposed in the La Panza Range to the west of the Chimineas fault (Ross, 1972; 1984) and in the Mount Pinos area to the southeast of Cuyama Valley (Dibblee, 1982; Kellogg and others, 2008), and (2) Paleoproterozoic granitic gneiss that is exposed at 
Barrett Ridge just east of the La Panza Range (Ross, 1972; 1984) and to the east of the Cuyama Badlands (Kellogg and others, 2008) (fig. 1).

Thirty-nine wells in the study area penetrate crystalline rocks at depth (fig. 11). These rocks are primarily identified from description of cuttings samples, although these rocks can often be distinguished on electric logs from overlying sedimentary rocks by an increase in resistivity values (fig. 8C). The subsurface occurrences are in the northwest part of the Caliente Range, to the east of the buried trace of the Russell fault and in the southeast part of the Cuyama Badlands near outcrops of basement rocks. 


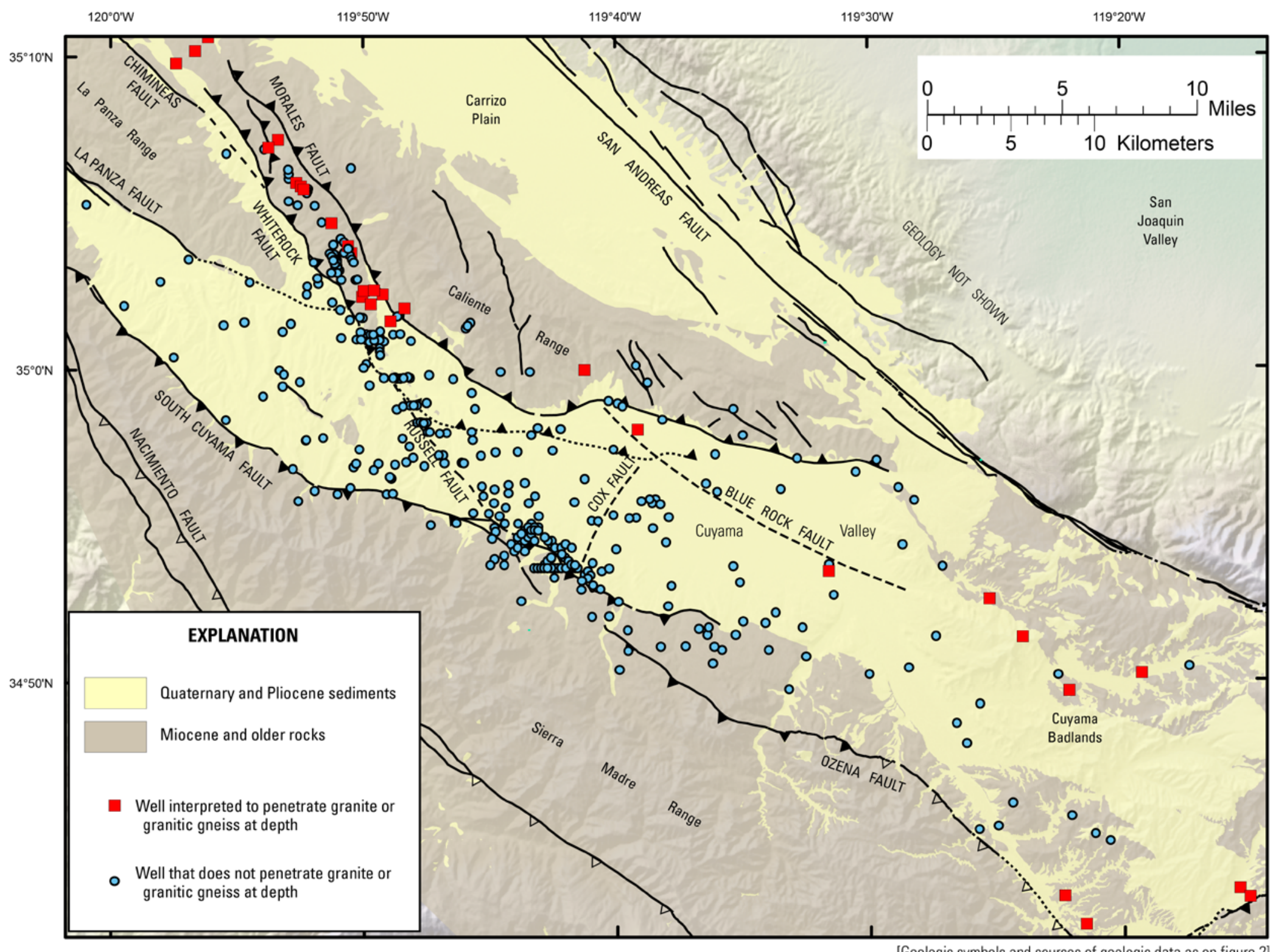

Figure 11. Map showing the location of wells in Cuyama Valley that penetrate granite or granitic gneiss at depth. 
COMMENTS: Any additional information not easily added to one of the previously described columns. Entries in this column are in part derived from the CA DOGGR prospect well data and our annotations.

\section{Summary}

This data tabulation includes stratigraphic information from selected oil and gas exploration wells from Cuyama Valley and surrounding areas. Data are compiled from various sources and reduced to a limited number of stratigraphic units. This report makes available in digital form a large subsurface well dataset, so that these data are available for incorporation within a geographic information system (GIS) and use in the construction of three-dimensional geologic framework models that can be used to address regional stratigraphic and structural questions.

\section{Acknowledgments}

Staff at the State of California Department of Conservation, Division of Oil, Gas, and Geothermal Resources, Santa Maria district office, provided assistance in accessing records for petroleum exploration drill holes from Cuyama Valley and in the scanning of electric logs. Emily Taylor (USGS, Denver) and Meghan Patterson (at the time, a student at Metropolitan State College of Colorado) transcribed paper drill-hole records into digital files. 


\section{References Cited}

Ballance, P.F., Howell, D.G., and Ort, K., 1983, Late Cenozoic wrench tectonics along the Nacimiento, South Cuyama, and La Panza faults, California, indicated by depositional history of the Simmler Formation, in Andersen, D.W. and Rymer, M.J., eds., Tectonics and sedimentation along faults of the San Andreas system: Pacific Section, Society of Economic Paleontologists and Mineralogists (SEPM), v. 30, p. 1-9.

Barger, R.M., and Zulberti, J.L., 1952, Russell Ranch oil field: California Division of Oil and Gas, California Oil Fields Summary of Operations, v. 38, no. 2, p. 5-10.

Bartow, J.A., 1978, Oligocene continental sedimentation in the Caliente Range area, California: Journal of Sedimentary Petrology, v. 48, p. 75-78.

Bartow, J.A., 1990, Coarse-grained deltaic sedimentation in the Miocene Cuyama strike-slip basin, California Coast Ranges: Sedimentary Geology, v. 68, p. 17-38.

Bartow, J.A., 1995, Gilbert-type deltas in a Miocene marine sequence, Cuyama Basin, Southern California, in Fritsche, A.E., ed., Cenozoic paleogeography of the western United States-II: Pacific Section, SEPM (Society for Sedimentary Geology), book 75, p. 42-52.

Bazeley, W.J.M., ed., 1988, Tertiary Tectonics and Sedimentation in the Cuyama Basin, San Luis Obispo, Santa Barbara, and Ventura Counties, California: Society of Economic Paleontologists and Mineralogists (SEPM), Pacific Section, Cuyama symposium and field trip guidebook, v. 59, $173 \mathrm{p}$. Blake, T.P., 1982, Depositional environments of the Simmler Formation in southern Cuyama Valley, Santa Barbara and Ventura counties, California, in Ingersoll, R.V. and Woodburne, M.O., eds., Cenozoic nonmarine deposits of California and Arizona: Society of Economic Paleontologists and Mineralogists (SEPM), p. 35-50.

Burgan, John, 1949, Twenty-million-dollar valley: Saturday Evening Post, December 31, 1949, vol. 222, issue 27, p. 16.

Calhoun, J.A., 1986, Structural geology of the Morales Canyon and Taylor Canyon region of the Cuyama basin, southern Coast Ranges, California: Corvallis, Oregon State University, M.S. thesis, 86 p., 18 pls., 9 figs.

California Department of Conservation, 2009, 2008 Annual Report of the State Oil and Gas Supervisor: Sacramento, California Department of Conservation Division of Oil, Gas and Geothermal Resources, Publication PR06, 265 p., accessed February, 2010, at ftp://ftp.consrv.ca.gov/pub/oil/annual_reports/2008/.

California Department of Conservation, Division of Oil and Gas, 1982, Oil and Gas Prospect Wells Drilled in California Through 1980: Sacramento, California Department of Conservation, Division of Oil, Gas and Geothermal Resources, Report TR01, 258 p.

Chipping, D.H., 1970, The petrology and paleogeography of Cretaceous and lower Tertiary strata in the vicinity of Cuyama Valley: Stanford, California, Stanford University, Ph.D. dissertation, 184 p.

Chipping, D.H., 1972, Early Tertiary paleogeography of central California: American Association of Petroleum Geologists Bulletin, v. 56, p. 480-493.

Clifton, H.E., 1981, Progradational sequences in Miocene shoreline deposits, southeastern Caliente Range, California: Journal of Sedimentary Petrology, v. 51, p. 165-184.

Davis, T.L., Lagoe, M.B., Bazeley, W.J.M., Gordon, Stuart, Mcintosh, Kirk, and Namson, J.S., 1988, Structure of the Cuyama Valley, Caliente Range, and Carrizo Plain and its significance to the structural style of the southern Coast Ranges and western Transverse Ranges, in Bazeley, W.J.M., ed., Tertiary Tectonics and Sedimentation in the Cuyama Basin, San Luis Obispo, Santa Barbara, and 
Ventura Counties, California: Pacific Section, Society of Economic Paleontologists and Mineralogists (SEPM), Cuyama symposium and field trip, Guidebook, April 16-18, 1988, v. 59, p. 159-161.

DeLong, S.B., Pelletier, J.D., and Arnold, L.J., 2008, Climate change triggered sedimentation and progressive tectonic uplift in a coupled piedmont-axial system-Cuyama Valley, California, U.S.A.: Earth Surface Processes and Landforms, v. 33, p. 1033-1046.

Dibblee, T.W., Jr., ed., 1972, Geologic map of fourteen 15-minute quadrangles along the San Andreas fault in the vicinity of Paso Robles and Cholame southeastward to Maricopa and Cuyama, California: U.S. Geological Survey Open-File Report 72-89, scale 1:62,500.

Dibblee, T.W. Jr., 1973, Stratigraphy of the southern Coast Ranges near the San Andreas fault from Cholame to Maricopa, California: U.S. Geological Survey Professional Paper 764, 45 p.

Dibblee, T.W., Jr., 1982, Geology of the Alamo Mountain, Frazier Mountain, Lockwood Valley, Mount Pinos, and Cuyama badlands areas, southern California, in Fife, D.L., and Minch, J.A., eds., Geology and mineral wealth of the California Transverse Ranges (Mason Hill volume): Santa Ana, California, South Coast Geological Society, p. 57-77.

Dibblee, T.W., Jr., 1995, Tectonic and depositional environment of middle and upper Cenozoic sequences of coastal southern California region, in Fritsche, A.E., ed., Cenozoic paleogeography of the western United States - II: Pacific Section, Society of Economic Paleontologists and Mineralogists (SEPM), v. 75, p. 213-245.

Eaton, J.E., Grant, U.S., and Allen, H.B., 1941, Miocene of Caliente Range and environs, California: American Association Petroleum Geologists Bulletin, v. 25, p. 193-262, 9 pls.

Ellis, B.J., 1994, Changing tectonic regimes in the southern Salinian block-Extension, strike-slip faulting, compression and rotation in the Cuyama Valley, California: Corvallis, Oregon State University, Ph.D. dissertation, 141 p., 31 figs.

Ellis, B.J., and Spitz, H.M., 1987, Subsurface cross-section of the southeastern Cuyama basin, southern California, in Davis, T.L., and Namson, J.S., eds., Structural Evolution of the Western Transverse Ranges: Pacific Section, Society of Economic Paleontologists and Mineralogists (SEPM), v. 48A, p. 77-84.

Ellis, B.J., Levi, Shaul, and Yeats, R.S., 1993, Magnetic stratigraphy of the Morales Formation: Late Neogene clockwise rotation and compression in the Cuyama Basin, California Coast Ranges: Tectonics, v. 12, p. 1170-1179.

Fritsche, A.E., 1988, Origin and paleogeographic development of the Tertiary Cuyama depositional basin, southern California, in Bazeley, W.J.M., ed., Tertiary tectonics and sedimentation in the Cuyama basin, San Luis Obispo, Santa Barbara, and Ventura Counties, California: Pacific Section, Society of Economic Paleontologists and Mineralogists (SEPM), Cuyama symposium and field trip, Guidebook, April 16-18, 1988, v. 59, p. 159-162.

Graham, S.A., 1978, Role of the Salinian block in the evolution of the San Andreas fault system, California: American Association of Petroleum Geologists Bulletin, v. 62, p. 2214-2231.

Graham, S.E., Mahony, T.M., Blissenbach, J.L., Mariant, J.J., and Wentworth, C.M., 1999, Regional geologic map of San Andreas and related faults in Carrizo Plain, Temblor, Caliente and La Panza Ranges and vicinity, California-A digital database: U.S. Geological Survey Open-File Report 99-14, scale 1:125,000.

Hill, M.L., Carlson, S.A., and Dibblee, T.W., Jr., 1958, Stratigraphy of Cuyama Valley-Caliente Range area, California: American Association of Petroleum Geologists Bulletin, v. 42, no. 12, p. 2973-3000. Howell, D.G., Vedder, J.G., McLean, Hugh, Joyce, J.M., Clarke, S.H., Jr., and Smith, Greg, 1977, Review of Cretaceous geology, Salinian and Nacimiento blocks, Coast Ranges of central California, in Howell, D.G., Vedder, J.G., and McDougall, K.A., eds., Cretaceous geology of the California 
Coast Ranges, west of the San Andreas fault: Pacific Section, Society of Economic Paleontologists and Mineralogists (SEPM), Pacific Coast Paleogeography Field Guide 2, p. 1-46.

Johnson, D.E., and Pile, K.E., 2002, Well logging in nontechnical language (2nd ed.): Tulsa, Okla., PennWell Publishing, 289 p.

Kellogg, K.S., Minor, S.A., and Cossette, P.M., 2008, Geologic map of the eastern three-quarters of the Cuyama 30' x 60' quadrangle, California: U.S. Geological Survey Scientific Investigations Map 3002, scale 1:100,000, 2 plates, 1 pamphlet, $23 \mathrm{p}$.

Keys, Scott, and MacCary, L.M., 1971, Application of borehole geophysics to water-resources investigations: U.S. Geological Survey Techniques of Water-Resources Investigations, book 2, chap. E1, 126 p.

Kleinpell, R.M., 1938, Miocene stratigraphy of California: Tulsa, Okla., American Association of Petroleum Geologists, 450 p.

Lagoe, M.B. 1981, Subsurface facies analysis of the Saltos Shale Member, Monterey Formation (Miocene) and associated rocks, Cuyama Valley, California, in Carrison, R.E. and Douglas, R.G., eds., The Monterey Formation and Related Siliceous Rocks of California: Pacific Section, Los Angeles, Calif., Society of Economic Paleontologists and Mineralogists (SEPM), p. 199-211.

Lagoe, M.B., 1984, Paleogeography of Monterey Formation, Cuyama Basin, California: American Association of Petroleum Geologists Bulletin, v. 68, p. 610-627.

Lagoe, M.B., 1987, Middle Cenozoic basin development, Cuyama Basin, California, in Ingersoll, R.V. and Ernst, W.G., eds., Cenozoic basin development of coastal California, Rubey Volume VI:

Englewood Cliffs, N.J., Prentice-Hall, p. 172-206.

Nevins, B.B., 1982, Structural evolution of the Russell Ranch oil field and vicinity, southern Coast Ranges, California: Corvallis, Oregon State University, M.S. thesis, 76 p., 17 pls., 12 figs.

Perri, M.L., and Fritsche, A.E., 1988, Stratigraphy and depositional environments of the Miocene Branch Canyon Formation in the Sierra Madre, Caliente Range, and Sespe Creek areas, California, in Bazeley, W.J.M., ed., Tertiary Tectonics and Sedimentation in the Cuyama Basin, San Luis Obispo, Santa Barbara, and Ventura Counties, California: Pacific Section, Society of Economic Paleontologists and Mineralogists (SEPM), Cuyama symposium and field trip, Guidebook, April 16-18, 1988, v. 59, p. 87-98.

Prothero, D.R., 2001, Chronostratigraphic calibration of the Pacific Coast Cenozoic - A summary, in Prothero, D.R., ed., Magnetic stratigraphy of the Pacific Coast Cenozoic_-Proceedings of the 1997 Pacific Section AAPG-SEPM Meeting, Bakersfield, Calif., and the 2001 Pacific Section AAPGSEPM-Cordilleran Section GSA Meeting, Universal City, Calif.: Pacific Section SEPM, book 91, p. 377-394.

Reed, R.D. and Hollister, L.S., 1936, Structural evolution of southern California: Tulsa, Okla., American Association of Petroleum Geologists, 157 p.

Ross, D.C., 1972, Petrographic and chemical reconnaissance study of some granitic and gneissic rocks near the San Andreas fault from Bodega Head to Cajon Pass, California: U.S. Geological Survey Professional Paper 698, 92 p.

Ross, D.C., 1984, Possible correlations of basement rocks across the San Andreas, San Gregorio-Hosgri and Reliz-Rinconada-King City faults, California: U.S. Geological Survey Professional Paper 1317, $37 \mathrm{p}$.

Saucedo, G.J., Bedford, D.R., Raines, G.L., Miller, R.J., and Wentworth, C.M., 2000, GIS Data for the Geologic Map of California: Sacramento, California Department of Conservation, CD 2000-07. 
Schwade, I.T., Carlson, S.A., and O’Flynn, J.B., 1958, Geologic environment of Cuyama Valley oil fields, California, in Weeks, L.G., ed., Habitat of oil, a symposium: Tulsa, Okla., American Association of Petroleum Geologists, p. 78-99.

Schwing, H.F., 1982, Interaction between the Transverse Ranges and Salinian Block in the South Cuyama oil field, Cuyama Valley, California, in Fife, D.L., and Minch, J.A. eds., Geology and mineral wealth of the California Transverse Ranges-Mason Hill volume: South Coast Geological Society, p. 395-402.

Schwing, H.F., 1984, Subsurface geology of the South Cuyama oil field and adjacent areas, southern Coast Ranges, California: Corvallis, Oregon State University, M.S. thesis, 81 p., 19 pls., 10 figs. Spitz, H.M., 1986, Subsurface geology of the southeastern Cuyama Valley, southern Coast Ranges, California: Corvallis, Oregon State University, M.S. thesis, 88 p., 20 pls., 12 figs.

Stanley, R.G., 1995, Central Coastal Province (011), with a section on Cuyama Basin, by M.E. Tennyson, in Gautier, D.L., Dolton, G.L., Takahashi, K.I., and Varnes, K.L., eds., 1995 National assessment of United States oil and gas resources - Results, methodology, and supporting data: U.S. Geological Survey Digital Data Series DDS-30, Release 2, one CD-ROM, accessed February 2013, at http://certmapper.cr.usgs.gov/data/noga95/prov11/text/prov11.pdf.

Thomas, G.D., Fritsche, A.E., and Condon, M.W., 1988, Stratigraphy and depositional environments of the Hurricane Deck Formation, a new lower and middle Miocene, submarine-fan sandstone unit in the Sierra Madre and San Rafael Mountains, northeastern Santa Barbara County, California, in Bazeley, W.J.M., ed., Tertiary tectonics and sedimentation in the Cuyama basin, San Luis Obispo, Santa Barbara, and Ventura Counties, California: Pacific Section, Society of Economic Paleontologists and Mineralogists (SEPM), Cuyama symposium and field trip, Guidebook, April 16-18, 1988, v. 59, p. 71-86.

Upson, J.E. and Worts, G.F., Jr, 1951, Ground Water in the Cuyama Valley California: U.S. Geological Survey Water-Supply Paper 1110-B, 81 p., 1 plate.

Vedder, J.G., 1968, Geologic map of the Fox Mountain quadrangle, Santa Barbara County, California: U.S. Geological Survey Miscellaneous Investigations Map I-547, scale 1:24,000.

Vedder, J.G., 1973, Geologic framework and correlation of Miocene rocks in the Caliente Range, California, in Sedimentary facies changes in Tertiary rocks - California Transverse and southern Coast Ranges - 1973 annual meeting with the American Association of Petroleum Geologists and the Society of Economic Geophysicists: Society of Economic Paleontologists and Mineralogists (SEPM), Field trip 2, Guidebook, p. 42-53.

Vedder, J.G., and Repenning, C.A., 1975, Geologic map of Cuyama and New Cuyama Quadrangles, San Luis Obispo and Santa Barbara Counties, California, U.S. Geological Survey Miscellaneous Geologic Investigations Map I-876, scale 1:24,000, 2 plates.

Yeats, R.S., Calhoun, J.A., Nevins, B.B., Schwing, H.F., and Spitz, H.M., 1989, Russell Fault; early strike-slip fault of California Coast Ranges: American Association of Petroleum Geologists Bulletin, v. 73, p. 1089-1102.

Zulberti, J.L., 1954, South Cuyama oil field, in Summary of operations, California oil fields, fortieth annual report of the State oil and gas supervisor: San Francisco, California Department of Natural Resources, Division of Oil and Gas, v. 40, no. 1, p. 41-45. 


\section{Appendix 1. Stratigraphic Data from Oil And Gas Wells in Cuyama Valley and Surrounding Areas}

Data compiled within appendix 1 include well-location information and subsurface geologic information, including depths to stratigraphic tops, for oil and gas wells in Cuyama Valley and surrounding areas. Data column headings are written in an abbreviated format with no spaces to facilitate potential import of these tabular data into a geographic information system. Subsurface formations are generally listed in stratigraphic order, with stratigraphically highest units on the left and successively lower units to the right; parts of the section repeated by thrust faults are shown in separate columns that follow the same stratigraphic ordering scheme. The Caliente Formation (Tc) and the Branch Canyon Sandstone (Tbc) each are lateral equivalents of more than one unit. Wells may encounter these two units at varying stratigraphic positions, resulting in occasional apparent depth reversals in the data presented in appendix 1.

Data columns for some formation tops are preceded by a "less than" symbol in a separate column (LT) that is used to denote cases where the top of the formation is above the start of the electric $\log$, such that the top of the log only provides a maximum value for the drilled depth to the top of the stratigraphic unit. The symbol is listed in a separate column to avoid the appearance of non-numeric characters within the formation tops data column, facilitating use of these data within a geographic information system. The Simmler Formation (Tsi) has one formation top depth preceded by a "less than" symbol and one other value preceded by a "greater than" symbol, indicating a maximum and minimum value, respectively, for the drilled depth to the top of the stratigraphic unit. The symbols are shown in a separate column (LT_GT).

Data compiled within appendix 1 are presented as an Microsoft Excel file that has the following information:

Well location information

- Well ID number

- API well-identification number

- Operator name

- Lease name

- Well number

- County

- Field

- Township

- Range

- Section

- Benchmark

- Latitude

- Longitude

- Northing

- Easting

- Land surface altitude

- Measuring point

- Measuring point height

- Measuring point elevation

- Total depth of the hole 
$\underline{\text { Subsurface geologic information }}$

- Data source

- Fault

Depth to stratigraphic tops

- Santa Margarita Formation in second thrust plate (Tsm_T2)

- Monterey Formation, undivided in second thrust plate (Tm_T2)

- Branch Canyon Sandstone in second thrust plate (Tbc_T2)

- Whiterock Bluff Shale Member of the Monterey Formation in second thrust plate (Tmwr_T2)

- Saltos Shale Member of the Monterey Formation in second thrust plate (Tmsa_T2)

- Painted Rock Sandstone Member of the Vaqueros Formation in second thrust plate (Tvpr_T2)

- Morales Formation in first thrust plate (QTm_T1)

- Santa Margarita Formation in first thrust plate (Tsm_T1)

- Santa Margarita Formation and Branch Canyon Sandstone, undivided in first thrust plate (Tbs_T1)

- Branch Canyon Sandstone in first thrust plate (Tbc_T1)

- Whiterock Bluff Shale Member of the Monterey Formation in first thrust plate (Tmwr_T1)

- Saltos Shale Member of the Monterey Formation in first thrust plate (Tmsa_T1)

- Vaqueros Formation, undivided in first thrust plate (Tv_T1)

- Painted Rock Sandstone Member of the Vaqueros Formation in first thrust plate (Tvpr_T1)

- Soda Lake Sandstone Member of the Vaqueros Formation in first thrust plate (Tvs1_T1)

- Quail Canyon Sandstone Member of the Vaqueros Formation in first thrust plate (Tvqc_T1)

- Simmler Formation in first thrust plate (Tsi_T1)

- Pre-Oligocene marine sedimentary rocks, undivided in first thrust plate (TKu_T1)

- Morales Formation (QTm)

- Quatal Formation (Tq)

- Santa Margarita Formation (Tsm)

- Santa Margarita Formation and Branch Canyon Sandstone, undivided (Tbs)

- Caliente Formation (Tc)

- Branch Canyon Sandstone (Tbc)

- Monterey Formation, undivided (Tm)

- Whiterock Bluff Shale Member of the Monterey Formation (Tmwr)

- Saltos Shale Member of the Monterey Formation (Tmsa)

- Vaqueros Formation, undivided (Tv)

- Painted Rock Sandstone Member of the Vaqueros Formation (Tvpr)

- Soda Lake Shale Member of the Vaqueros Formation (Tvsl)

- Quail Canyon Sandstone Member of the Vaqueros Formation (Tvqc)

- Simmler Formation (Tsi)

- Pre-Oligocene marine sedimentary rocks, undivided (TKu)

- Granite and granitic gneiss, undivided (KXg)

- Comments 